\title{
Consumption Pattern Model for Malaysian Consumers
}

\author{
YATY SULAIMAN ${ }^{1}$, ABDUL SHUKOR SHAMSUDIN $^{1}$, \\ YEOH KHAR KHENG $^{1}$, ABDUL RAHIM OTHMAN ${ }^{1}$ \\ ${ }^{1}$ School of Business Management, College of Business, Universiti Utara Malaysia, Kedah, \\ MALAYSIA
}

\begin{abstract}
Consumption is expenses towards household goods and services such as clothing, food, entertainment, health services. Malaysian consumption trend consumers have been changing since 2005 as reported by consumer price index (CPI), per capita income and inflation rate due to inflation rate hikes at the end of 2016 and early 2017. This study examines the factors contributing to the consumption model of Malaysian consumers in rural and urban areas. Eight antecedents of Malaysian consumption pattern, consumer lifestyle, consumer value, consumer motive, consumer preference, and marketing mix of price, product, place, and advertising were measured using 7-point Likert scales. 1400 were questionnaires distributed to households, 851 were returned representing 61 percent response rate. The findings indicate support for validity of measurement models of all variables utilized for both model rural and urban. Structural Equation Modelling (SEM) of SMARTPLS 2.0 technique found that advertising is not a predictor for consumer motive for rural and urban. Apart from that, price hikes have been discussed. On the other hand, the rural model postulates better R2 than the other model. The finding implies that Malaysian government needs to conduct a continuous campaign to consumers regarding GST implementation and its consequences to them. Finally, the instability of the economy changed the consumption pattern throughout their lifestyle, value, motive and preferences.
\end{abstract}

Keywords: Consumption pattern, consumer lifestyle, consumer value, consumer motive, consumer preference, marketing mix

Received: December 2, 2019. Revised: May 10, 2020. Accepted: May 19, 2020. Published: May 21, 2020.

\section{Introduction}

Consumption pattern of Malaysian consumers these days is changing dramatically where they are paying higher money value to purchase products and services. This can be seen from the consumer price index which had a straight rise from $95.4 \%$ in 2000 to $119.6 \%$ in 2017. [1] mentioned that the Malaysian consumer consumption pattern has changed thoroughly since 2005 through several indicators as Consumer Price Index (CPI), per capita income and inflation rate. Malaysians per capita income rise at a very slow pace whereby it was USD6765 at the end of 2013 compared to USD5372 in 2005, a rise of only $26 \%$ in eight years where else rise in consumer prices was incomparable. The consumer price index (CPI) increased from 95.4 percent in 2000 to 119.6 percent in 2017 indicating that consumers are paying higher prices nowadays. Example, income growth raise more nutritionally food consumption [2].

Therefore, Malaysians will need to work harder by 121 percent to achieve the 2020 target of USD15, 000 per capita income (www.tradingeconomics.com). Food and nonalcoholic beverages (30 percent of total weight), housing, water, electricity, gas and other fuels (23 percent of total weight) and transport (15 percent) are having higher increase of consumer price index (Malaysia Inflation Rate.htm, retrieved on March 3, 2014) [3].

On top of that, the government implementation of Goods and Services Tax (GST) in 2015 has also increased the money value customers paying for products and services. Most Malaysians are having a stagnant annual salary with a higher cost of living causing them to buy less. Head of the Department of Resource Management and Consumer Studies Faculty of Human Ecology Universiti Putra Malaysia (UPM) Dr Mohamad Fazli Sabri mentioned that the inflation rate was about $3.2 \%$ in 2014 but the increase of annual salary of Malaysians were only about two to three \% causing them to spend most of their income on basic needs such as instalment payments for housing, transport, education and personal loans (Sinar Harian, December 2014). As mentioned by [4], purchase decisions are the phases overcome by consumers in determining the choice of products and services to be purchased

Specifically, the research model provides a relevant contribution to government policy where 
consumption pattern is critical for issues for citizens' standard of living in 2020. Consumption pattern of Malaysian changed markedly since 2005 as shown by several indicators such as consumer price index (CPI), per capita income and inflation rate. Although per capita income for Malaysia has risen but its at a very slow pace. It was USD5372 in 2005 and at the end of 2013 it has amplified to USD6765, a rise of 26 per cent. Therefore, Malaysia has to work effordly by 121 percent to achieve the 2020 target of USD15,000 per capita income (www.tradingeconomics.com). Apart from that, the government may formulate green technology policy towards environmental issues such as carbon emission index. Moreover, not putting a part for Rural and urban consumer price index where it may contribute to the purchasing power of consumers, inflation rate and comparative analysis of CPI. Finally, through this study, policy makers will be able to formulate a new consumption pattern model to enhance consumption pattern among the consumers from rural and urban areas in Malaysia.

\section{Literature review}

\subsection{Consumer Consumption Pattern}

Consumption pattern is the way of using, eating, or drinking something and the amount used or bought and consumers are the individuals who buy products and services for personal use and not for manufacture or resale. [5] suggested that predominate consumption pattern is predicted by predominate consumer lifestyle, use situations consumers face, predominate value, motive and preference system, physical landscape and psychological landscape meanwhile, [6] suggest the antecedents of food usage as lifestyle, degree of urbanization, personal and family situation, nutritional knowledge, quality conscious, weight conscious, health conscious, and socio-economic status as postulates, a model used for convenience food usage in Holland, adding into this, [7] examine 4Ps as the direct antecedents (price, product, place and advertising) of consumer motive in three Tesco Stores in Klang Valley, Malaysia in their model. All of these models are shown in Figure 2.10, 2.11 and 2.12 .
Figure. 2.10 Consumption Model 1. Adopted from Hawkins, Roupe \& Coney (1981)

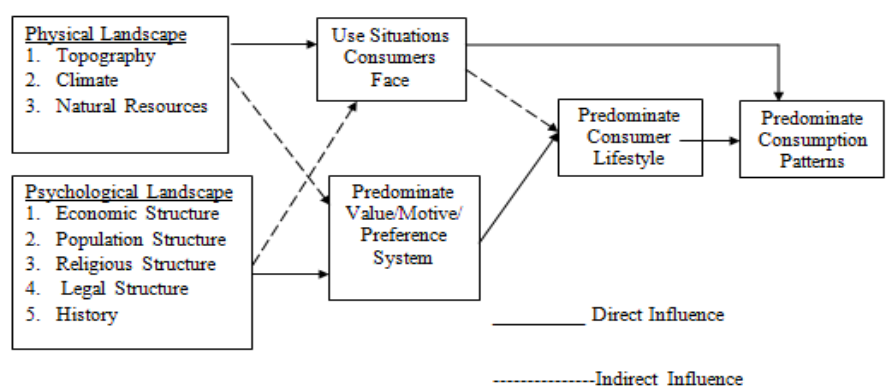

Figure. 2.11 Consumption Model 2 adopted from Veenma et al., (1995)

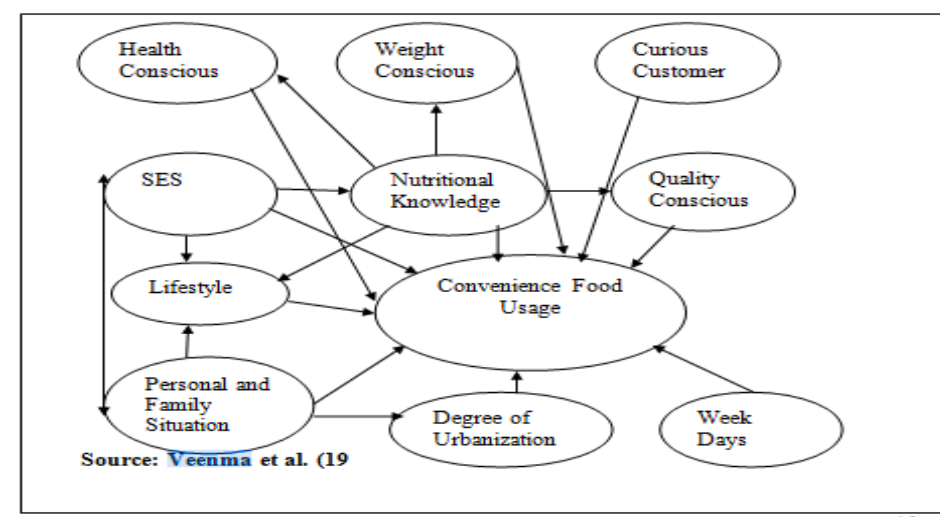

Figure. 2.12 Consumption Model 3 adopted from Munusamy and Hoo, (2008)

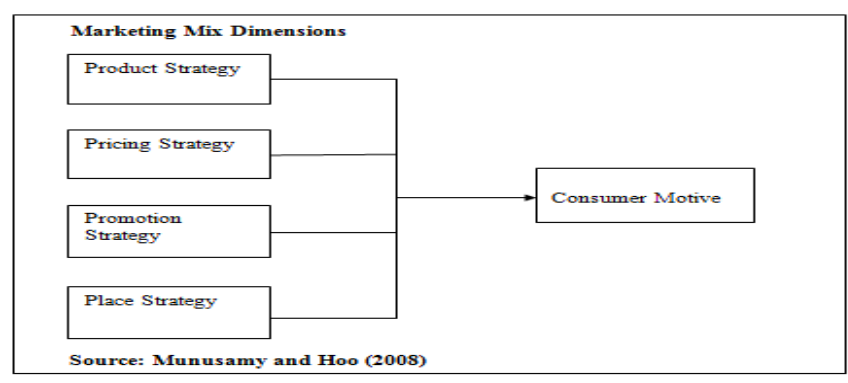

\subsection{Malaysians Consumption Pattern}

Malaysia is now one of the lowest consumer confidence ratings countries in Southeast Asia as they have become more concerned about the economy, increasing food prices and political stability. Nielsen Global Survey (2016) on 
Malaysian consumer confidence and spending interest reported that there is cautions spending amongst Malaysian consumers when it comes to saving any spare cash into savings after covering essential living expenses. As an example, only about a third of Malaysians are going for vacations or holidays. Apart from that, the survey also reveals that Malaysians are cautious for spending on new clothes in Q4 2016 (21\%, -15\% from past quarter), new technology products $(13 \%,-7 \%)$, home improvements/decorating $(13 \%,-5 \%)$ and out-ofhome entertainment $(16 \%,-3 \%)$. Two in five respondents are paying off debts, credit cards and loans with spare cash $(41 \%,+1 \%$ from previous quarter), funding their spare cash into retirement $(19 \%,-7 \%)$ and investing in shares of stock or mutual funds $(28 \%,-6 \%)$. The mean monthly household consumption expenditure for urban area has an increment rate of 9.3 per cent annually from RM2,465 to RM3,921 while at rural area also increased at a rate of 8.4 per cent annually from RM1,599 to RM2,431 for the period of 2009 to 2014. This study integrates the three consumption pattern models to formulate a new research framework for this study [5] and [7]

\subsection{The antecedents of Consumer Consumption Pattern}

Antecedents of consumer motive are price, product, place and advertising [7]. Direct predictors of consumption pattern are consumer lifestyle [5]; [6], real situations customers overcome [5], personal and family situation, socio economic status, quality conscious, lifestyle and curious [6]. Indirect factors of predominate consumption pattern are predominant value, motive, preference system, physical landscape, and psychological landscape [5]. This study observes direct antecedents of consumption pattern which are consumer lifestyle, indirect factors (mediators) as consumer value, consumer motive and consumer preference and four exogenous variables (price, product, place and advertising). Service providers should clearly understand the elements of marketing mix elements which will impact future and existing customers [8].

\subsubsection{Consumer Lifestyle}

Lifestyle is a mixture of motivations, needs and desires influenced by factors such as culture, family, reference groups and social class [9]. Constructs of lifestyle are used to describe one's personality, unity of the personality, opinion, common problems and the whole attitude of people's life [10]. Consumer lifestyle is a way of living that is influenced and reflected by one's consumption behaviour [11]. [12] highlighted lifestyle as someone's lifestyle with the social interaction with other groups and individuals, how an individual react in certain circumstances, knowing in advance the way he acted in a different situation, core interest of life, towards family, work, religion, politics, and more and finally lifestyles with relevant sociological variables such as religion, age, and social class.

\subsubsection{Consumer Value}

Value includes various perspectives, also from both the customer and supplier's point of view [13]; [14]. Values are the overall benefits consumers obtain and factor that forces the consumer's attitudes and concerns in making purchase decisions [15]. Meanwhile, [16] says that consumer value refers to people's experiences and learning process. [17]; [18]; [19] and [20] mentioned that it is good for the marketing managers to pay attention to customer value and adopt strategies related to it to promote business and sustain long-term success.

\subsubsection{Consumer Preference}

Consumer preference is their behaviour shown when they are searching, purchasing and disposing of products [21], it primarily used to choose a preference that has the greatest anticipated value among other choices to satisfy their needs and wants. Preferences are independent of the income and price and the ability to purchase does not determine consumer's likes and dislikes. [22] defines customer preference as (Individual) tastes as measured by various goods.

\subsection{Marketing Mix (4Ps)}

\subsubsection{Price}

Price is a vital element for marketing and organization, [23] mentioned that price is the only part of the marketing mix which can produce revenues. Price is the value of monetary paid and expression of consumers who agree to pay (Entrepreneurship Academy, 2012). [24] clarified that the price is the amount of money that consumers use to pay to get a product. Meanwhile, [4] mentioned that price can be interpreted as the amount of money (monetary unit) and (nonmonetary) aspects required in order to get a product or service. [25] confirmed that price is highly determined by the cost of the product, marketing strategy, distribution and advertising. 
[26], confirmed a positive relationship between price and customers' purchase decision and it also affects the quantity of goods purchased by consumers

\subsubsection{Product}

[27] define a product as anything that can be offered to a market for attention, accusations, use, or consumption that might satisfy a want or need and. [28] mentioned product as quality, design, features, brand name and sizes. Physical appearance and packaging of products has the possibility to influence consumer judgements and decisions and companies should focus the strategy of product differentiation and cost leadership to sustain products.

\subsubsection{Place}

Location plays a role in influencing consumer decisions to purchase a product. Place is where consumers will be able to get products or services [29], a suitable place will be able to attract many consumers spending habits and purchase behaviour [30], it is a process and methods by which products or services reaches customers also being an important element of marketing [31]. [32], says place is a position of product where it can be reached easily, safely and conveniently.

\subsubsection{Promotion}

Promotional activities include sales promotion, public relations, advertising and direct marketing. Promotion is one of the sales activities to inform consumers about the product existence to increase the demand and sales of the product. Promotion acts to inform, persuade and remind the market of the product so that it will be able to attract the feelings, beliefs and behaviour of consumers towards the product [33]. Promotion positively and significantly influences consumer on purchase decision [34] and it has a positive effect on purchase decision [35]. Types of promotion tools are samples, cash refunds, coupons, contests and games [36].

\subsection{Hypotheses development}

Based on the relevant literature review, the following section addresses the formulation of the hypotheses developed for this study.

H1: Consumer life style is a direct predictor of consumption pattern.

H2: Consumer value is a direct predictor of consumer life style

H3: Consumer motive is a direct predictor of consumer life style.
H4: Consumer preference is a direct predictor of consumer life style

H5a: Price is direct predictor of consumer value.

H5b: Product is a direct predictor of consumer value.

H5c: Place is a direct predictor of consumer value.

H5d: Promotion is a direct predictor of consumer value.

H6a: Price is direct predictor of consumer motive.

H6b: Product is a direct predictor of consumer motive.

H6c: Place is a direct predictor of consumer motive.

H6d: Promotion is a direct predictor of consumer motive.

H7a: Price is direct predictor of consumer preference.

H7b: Product is a direct predictor of consumer preference.

H7c: Place is a direct predictor of consumer preference.

H7d: Promotion is a direct predictor of consumer preference.

H8a: Consumer life style mediates the relationship between consumer value and consumption pattern. H8b: Consumer life style mediates the relationship between consumer motive and consumption pattern. H8c: Consumer life style mediates the relationship between consumer preference and consumption pattern.

H9a: Consumer value mediates the relationship between price, consumer life style and consumption pattern.

H9b: Consumer value mediates the relationship between product, consumer life style and consumption pattern.

H9c: Consumer value mediates the relationship between place, consumer life style and consumption pattern.

H9d: Consumer value mediates the relationship between promotion, consumer life style and consumption pattern.

H1Oa: Consumer motive mediates the relationship between price, consumer life style and consumption pattern.

H10b: Consumer motive mediates the relationship between product, consumer life style and consumption pattern.

H1Oc: Consumer motive mediates the relationship between place, consumer life style and consumption pattern.

H10d: Consumer motive mediates the relationship between promotion, consumer life style and consumption pattern. 
Hlla: Consumer preference mediates the relationship between price, consumer life style and consumption pattern.

H11b: Consumer preference mediates the relationship between product, consumer life style and consumption pattern.

H11c: Consumer preference mediates the relationship between place, consumer life style and consumption pattern.

HIld: Consumer preference mediates the relationship between promotion, consumer life style and consumption pattern.

\section{Methodology}

\subsection{Conceptual framework}

Figure 3.1 below depicts the conceptual framework of this study based on the discussion of variables in the literature review section.

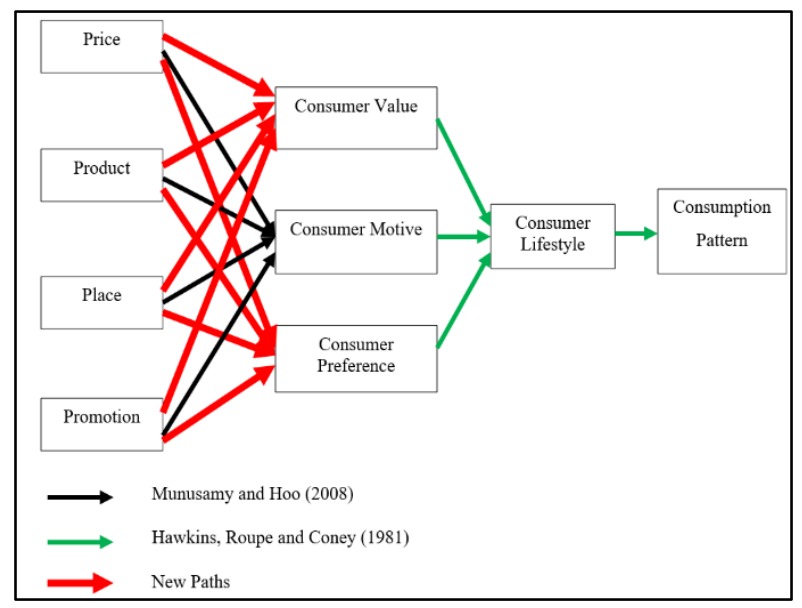

Figure. 3. 1 Research framework developed in this study which are extended model from [7] and [5].

\subsection{Description of Methodology}

Two research designs utilized. The nature of this study is a cross-sectional research whereby the data is collected, analysed, and summarized statistically and conclusions are drawn at a single point in time and adopted a cross-sectional data approach in the data collection process. This study approached the respondents in two specific geographic segments i.e. rural and urban segments. The unit analysis of this study was the actual consumers who have purchasing power in their hands and covers two specific geographic segments of rural and urban area. The sampling frame was 7 states (Kedah, Kelantan, Johor, Penang, Terengganu, Selangor/Kuala Lumpur and Sarawak) in Malaysia with the population of about 5 million. The sample size from each state was 200 respondents, totalling sample size of 1400 (200x7) (Table 3.1). We took rural consumers from 3 states (Kelantan, Kedah, and Terengganu) and urban consumers in 3 states in urban areas (Selangor/Kuala Lumpur, Johor and Penang). For Sarawak, both rural and urban consumers were chosen.

Table 3.1

Sample size for the state Kedah, Kelantan, Terengganu, Johor, Penang, Kuala Lumpur/Selangor and Sarawak

\begin{tabular}{lll}
\hline State & $\begin{array}{l}\text { Population } \\
\text { (Millions) }\end{array}$ & $\begin{array}{l}\text { Sample } \\
\text { Size }\end{array}$ \\
\hline Kedah & 295,624 & 200 \\
Kelantan & $1,459,994$ & 200 \\
Terengganu & 343,284 & 200 \\
Johor & 916,409 & 200 \\
Penang & 227,972 & 200 \\
KL/Selangor & $1,309,898$ & 200 \\
Sarawak & $2,471,140$ & 200 \\
\hline
\end{tabular}

\subsection{Data collection method}

Quantitative research was designed for this study. The respondents were identified through the statistic of population around Malaysia. Research assistants (UUM Students) were assigned to distribute the questionnaires in 7 States in Malaysia which is Kedah, Kelantan, Johor, Penang, Terengganu, Selangor/Kuala Lumpur and Sarawak with a total of 200 set of questionnaires in each state.

\subsection{Measurement}

All variables were measured using 7-point Likert scale from1-strongly disagree to 7 -strongly agree. Variables (price, product, place, advertising, consumer value, consumer motive, consumer preference, consumer lifestyle, and consumption pattern) were adapted from past literature. A total of 30 items were adopted from [37] for consumption pattern variable with internal consistency more than 0.80 . As for consumer lifestyle, 8 items were adopted from [38] with internal consistency more than 0.80 .10 items were adopted from [39] for consumer value and 10 items of consumer motive were adopted from [40], and 21 items adopted from [41] for consumer preference. For marketing mix of

product, pricing, promotion and place, the items were adopted from [42]. 


\section{Findings}

A total of 1400 sets of questionnaires were distributed in 7 states in Malaysia which is Kedah, Kelantan, Johor, Penang, Terengganu, Selangor/Kuala Lumpur and Sarawak with 200 set of questionnaires each states. Out of 1400 sets of questionnaires, 851 sets were returned as illustrated in Table 4.1 and Table 4.2 illustrates the demographic profile of respondents.

Table 4.1

Respondents' Response Rate

\begin{tabular}{llll}
\hline States & Distributed Questionnaires & Returned and & Percentage \\
& Usable & $(\mathbf{1 0 0 \% )})$
\end{tabular}

\begin{tabular}{lccc}
\hline Kedah & 200 & 156 & 78 \\
Kelantan & 200 & 130 & 65 \\
Johor & 200 & 104 & 52 \\
Penang & 200 & 143 & 72 \\
Terengganu & 200 & 89 & 45 \\
& & & 76 \\
Selangor/KL & 200 & 151 & \\
& & & 39 \\
Sarawak & 200 & $\mathbf{8 5 1}$ & $\mathbf{6 1}$ \\
TOTAL & $\mathbf{1 4 0 0}$ & & \\
\hline
\end{tabular}


Table 4.2

Demographic Profile of respondents $(n=851)$

\begin{tabular}{|c|c|c|}
\hline Demographic & Frequency $(n=851)$ & Percentage (\%) \\
\hline \multicolumn{3}{|l|}{ Gender } \\
\hline Male & 420 & 49.9 \\
\hline Female & 431 & 50.6 \\
\hline \multicolumn{3}{|l|}{$\underline{\text { Marital status }}$} \\
\hline Single & 385 & 45.2 \\
\hline Married & 466 & 54.8 \\
\hline \multicolumn{3}{|l|}{ Ethnicity } \\
\hline Malay & 711 & 83.5 \\
\hline Chinese & 79 & 9.3 \\
\hline Indian & 45 & 5.3 \\
\hline Others & 16 & 1.9 \\
\hline \multicolumn{3}{|l|}{ Religion } \\
\hline Muslim & 715 & 84.0 \\
\hline Buddhist & 63 & 7.4 \\
\hline Hindu & 38 & 4.5 \\
\hline Christian & 35 & 4.1 \\
\hline \multicolumn{3}{|l|}{ Level of education } \\
\hline$\overline{S P M}$ & 233 & 27.4 \\
\hline STPM & 88 & 10.3 \\
\hline Undergraduate & 351 & 41.2 \\
\hline Master & 123 & 14.5 \\
\hline PHD & 15 & 1.8 \\
\hline Others & 41 & 4.8 \\
\hline \multicolumn{3}{|l|}{ Occupation } \\
\hline \multicolumn{3}{|l|}{ Self-employed / Business } \\
\hline Private sector employee & 85 & 10.0 \\
\hline Government employee & 345 & 40.5 \\
\hline Student & 258 & 30.3 \\
\hline Housewife & 144 & 16.9 \\
\hline \multirow{2}{*}{ Unemployed } & 14 & 1.6 \\
\hline & 5 & 0.6 \\
\hline \multicolumn{3}{|l|}{ Duration of work } \\
\hline Less than 5 years & 397 & 46.7 \\
\hline $6-10$ years & 222 & 26.1 \\
\hline 11 - 15 years & 94 & 11.0 \\
\hline 16 - 20 years & 83 & 9.8 \\
\hline More than 21 years & 55 & 6.5 \\
\hline \multicolumn{3}{|l|}{ Neighbourhood type } \\
\hline Urban & 554 & 65.1 \\
\hline Rural & 297 & 34.9 \\
\hline \multicolumn{3}{|l|}{ Housing type } \\
\hline Terraced House & 274 & 32.2 \\
\hline Detached House & 108 & 12.7 \\
\hline Bungalow & 92 & 10.8 \\
\hline Apartment / Condo & 227 & 26.7 \\
\hline Village House & 141 & 16.6 \\
\hline Others & 9 & 1.1 \\
\hline
\end{tabular}




\begin{tabular}{|c|c|c|}
\hline \multicolumn{3}{|l|}{ Accommodation } \\
\hline Rent & 377 & 44.3 \\
\hline Owner & 474 & 55.7 \\
\hline \multicolumn{3}{|l|}{ Monthy gross income } \\
\hline$<$ RM 2000 & 318 & 37.4 \\
\hline RM 2001 - RM 4000 & 344 & 40.4 \\
\hline RM 4001 - RM 6000 & 129 & 15.2 \\
\hline RM 6001 - RM 8000 & 41 & 4.8 \\
\hline$>$ RM 8000 & 19 & 2.2 \\
\hline
\end{tabular}

\subsection{Descriptive Analysis}

Descriptive analysis was conducted to obtain a detailed idea about respondents and to describe and summarize the characteristics of each construct, namely consumption pattern, consumer lifestyle, consumer value, consumer motive, consumer preference, product, price, promotion and place though mean and standard deviation. Table 4.2 shows the minimum, maximum, mean and standard deviation of the constructs. The minimum and maximum value was representing the Likert scale that used in this study. The current study used a seven-point Likert Scale (1=Strongly disagree to $7=$ Strongly agree) to measure the feedbacks of the respondents to all the items given in the questionnaire. The minimum value of the constructs was 1.00 and maximum value is 7.00 . The mean of most variables is in the average range from 4.8644 to 5.1219 . The standard deviation range is from 0.80785 to 0.9488 . All the constructs in Table 4.3 show that there are above the acceptable level and is at a satisfactory level.

Table 4.3

Descriptive Statistics of the Constructs $(n=851)$

\begin{tabular}{llccl}
\hline Constructs & Minimum & Maximum & Mean & Std. Deviation \\
\hline Consumption Pattern & 2.18 & 7.00 & 4.9618 & 0.90613 \\
Consumer Lifestyle & 1.44 & 7.00 & 4.9251 & 0.91698 \\
Consumer Value & 1.00 & 7.00 & 4.9545 & 0.89289 \\
Consumer Motive & 2.38 & 7.00 & 5.1271 & 0.90677 \\
Consumer Preference & 1.69 & 7.00 & 4.8819 & 0.85216 \\
Product & 2.20 & 7.00 & 4.8987 & 0.81552 \\
Price & 1.85 & 7.00 & 4.8644 & 0.80785 \\
Promotion & 1.00 & 7.00 & 4.9187 & 0.9488 \\
Place & 1.30 & 7.00 & 5.1219 & 0.92702 \\
\hline
\end{tabular}

Study was analysed by using PLS-SEM 2.0 as being a powerful analysis to review complex models. It includes response rate, demographic profile of the respondents, data coding and data entry, descriptive analysis, content validity of the measure, the discriminant validity, the theoretical framework and hypothesis testing, mediating effects of urban area and mediating effects of rural area. Those analysis are shown in Figure 1, 2, 3 4, 5 and 6. 
Figure. 1. Measurement model for consumption pattern model.

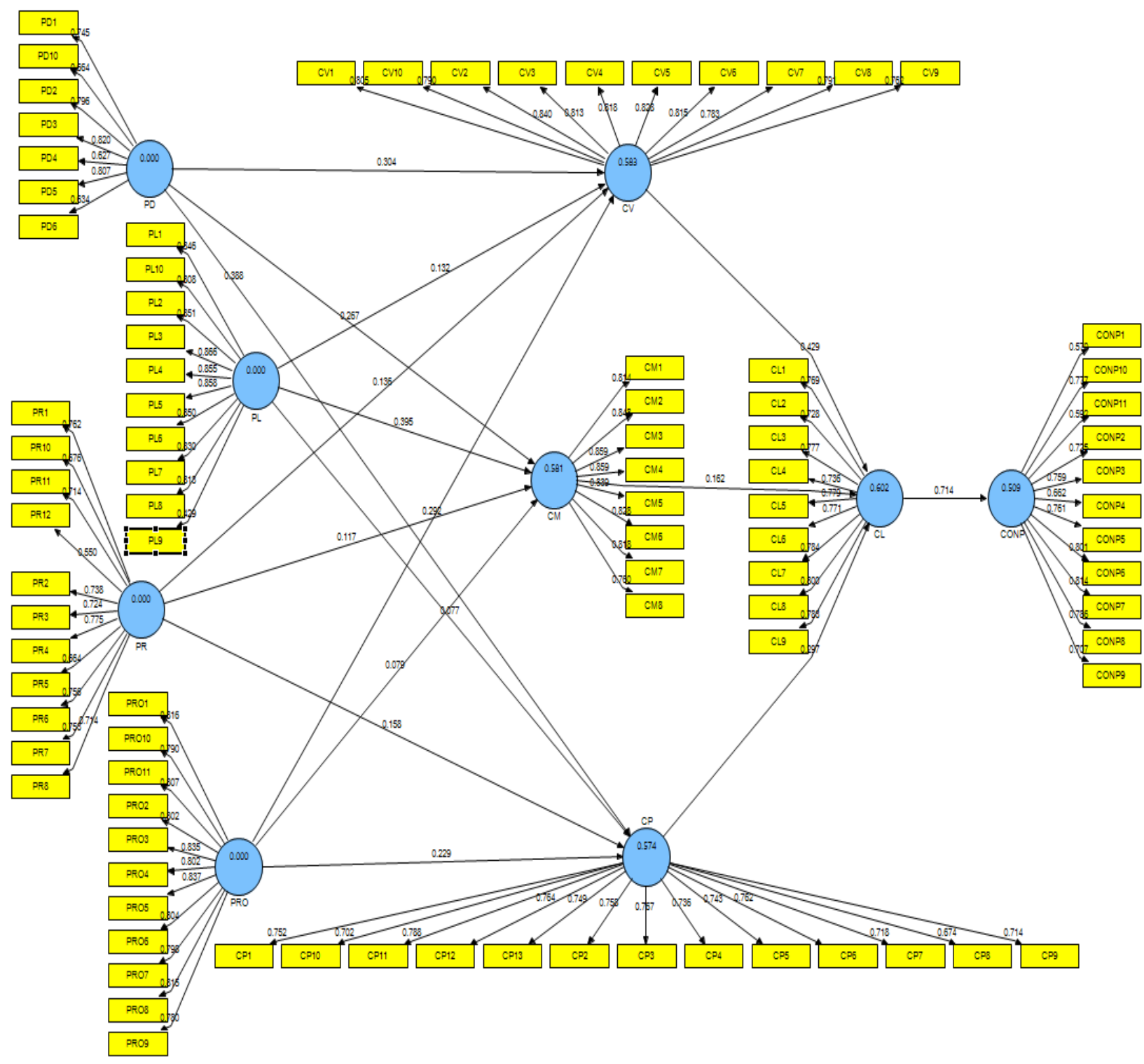


Figure.2. Structural model for consumption pattern model.

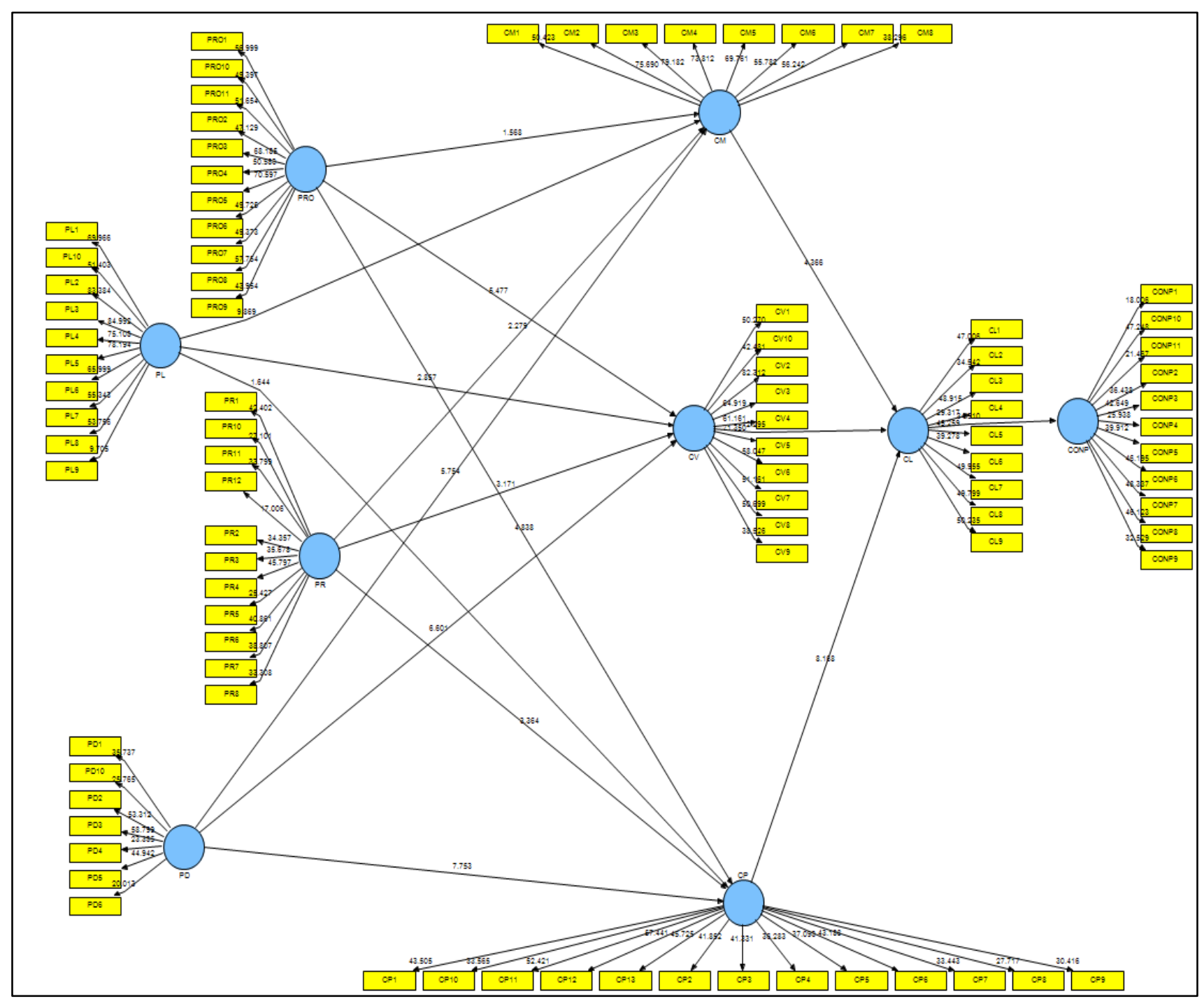


Figure.3. Measurement model for consumption pattern model in rural area.

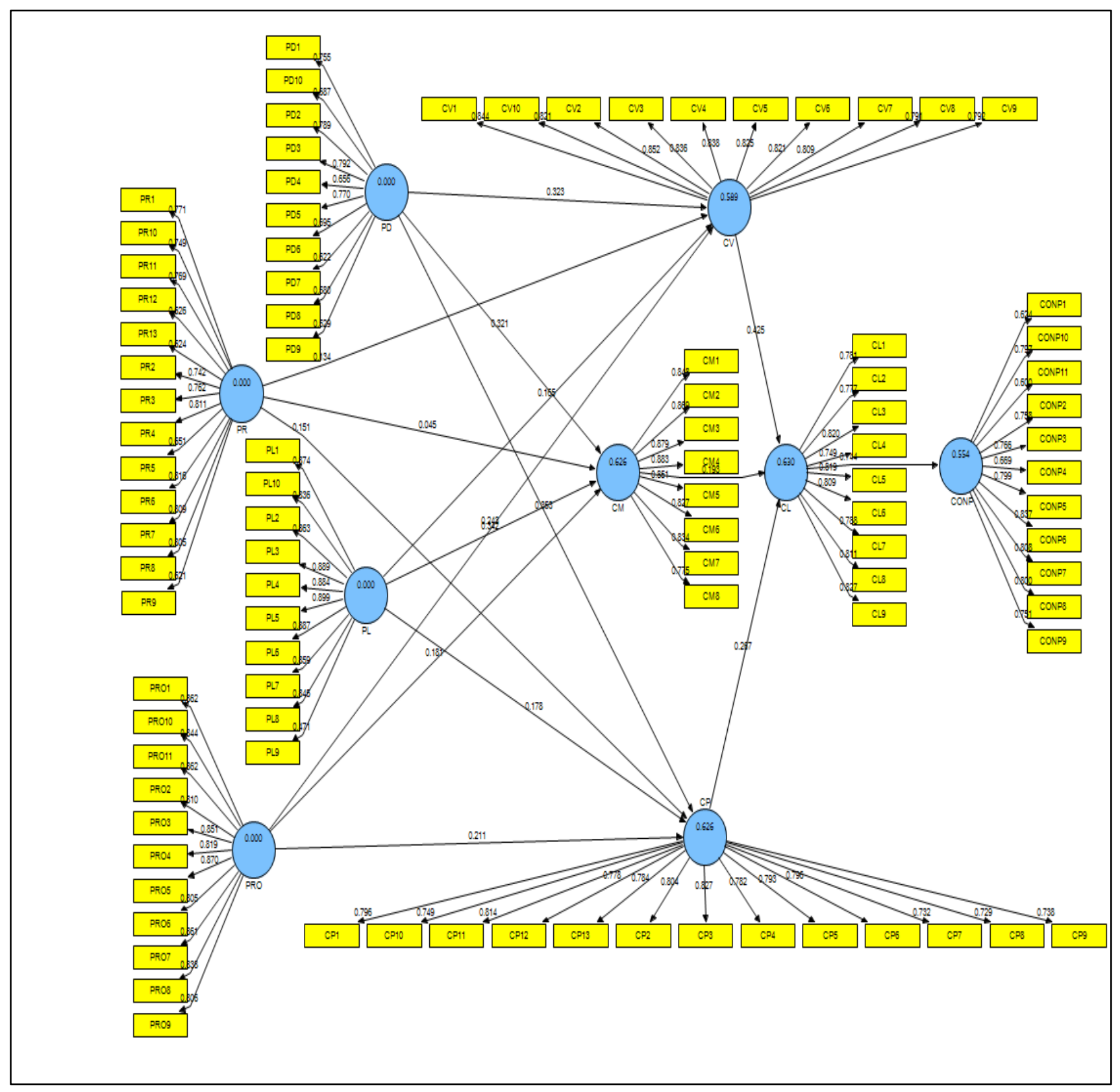


Figure.4. Structural model for consumption pattern model in rural area.

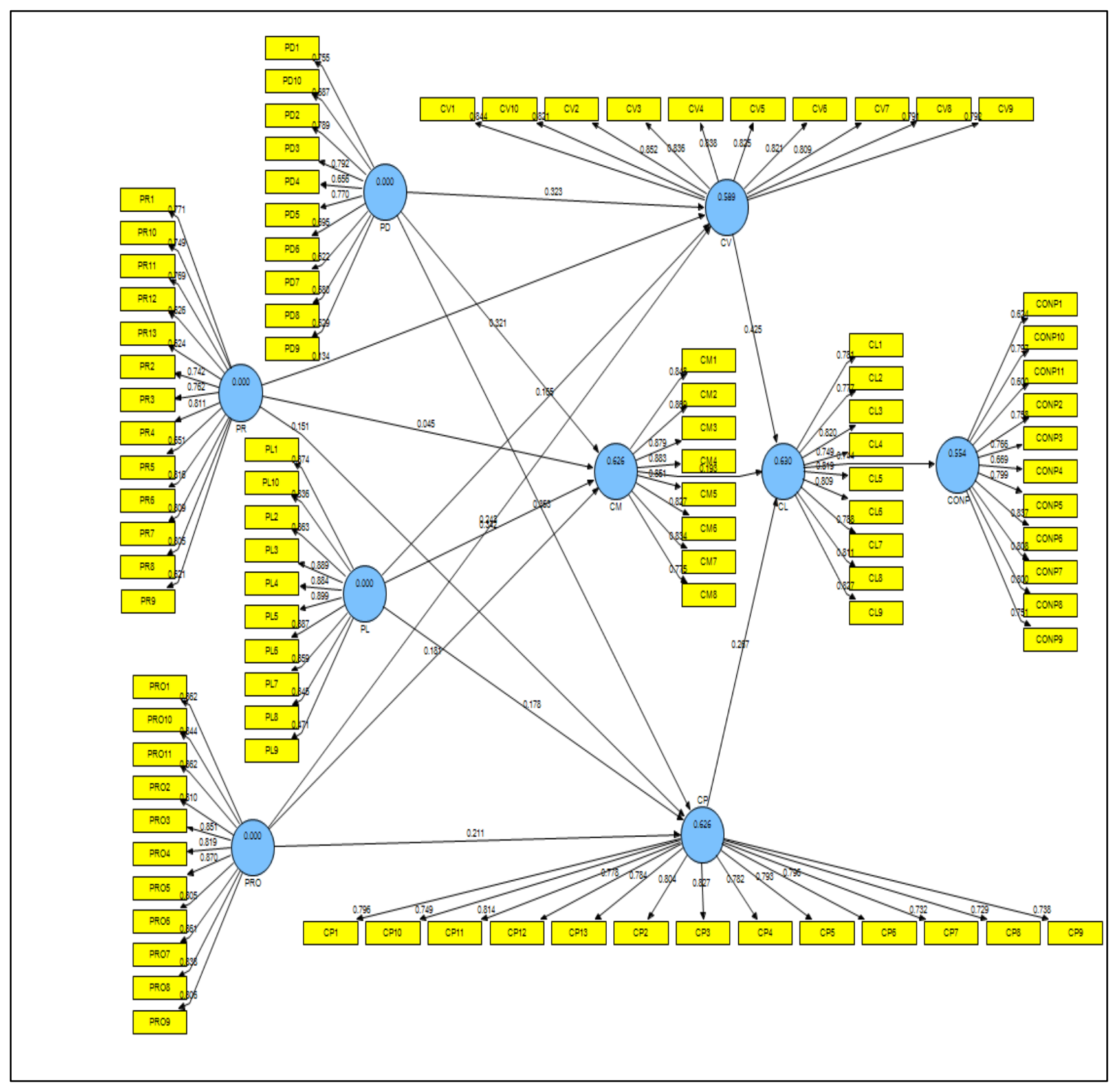


Figure.5. Measurement model for consumption pattern model in urban area.

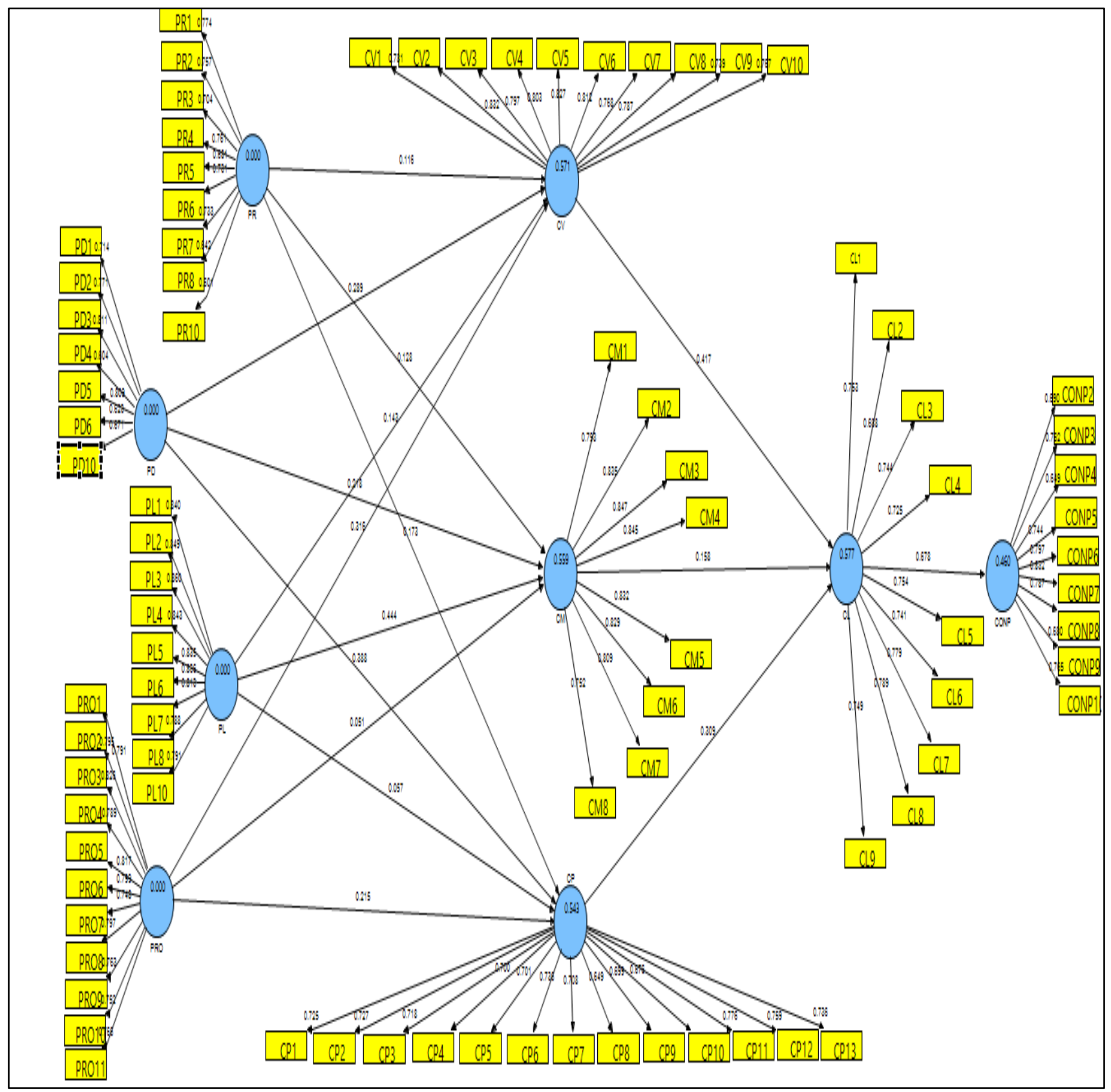


Figure.6. Structural model for consumption pattern model in urban area.

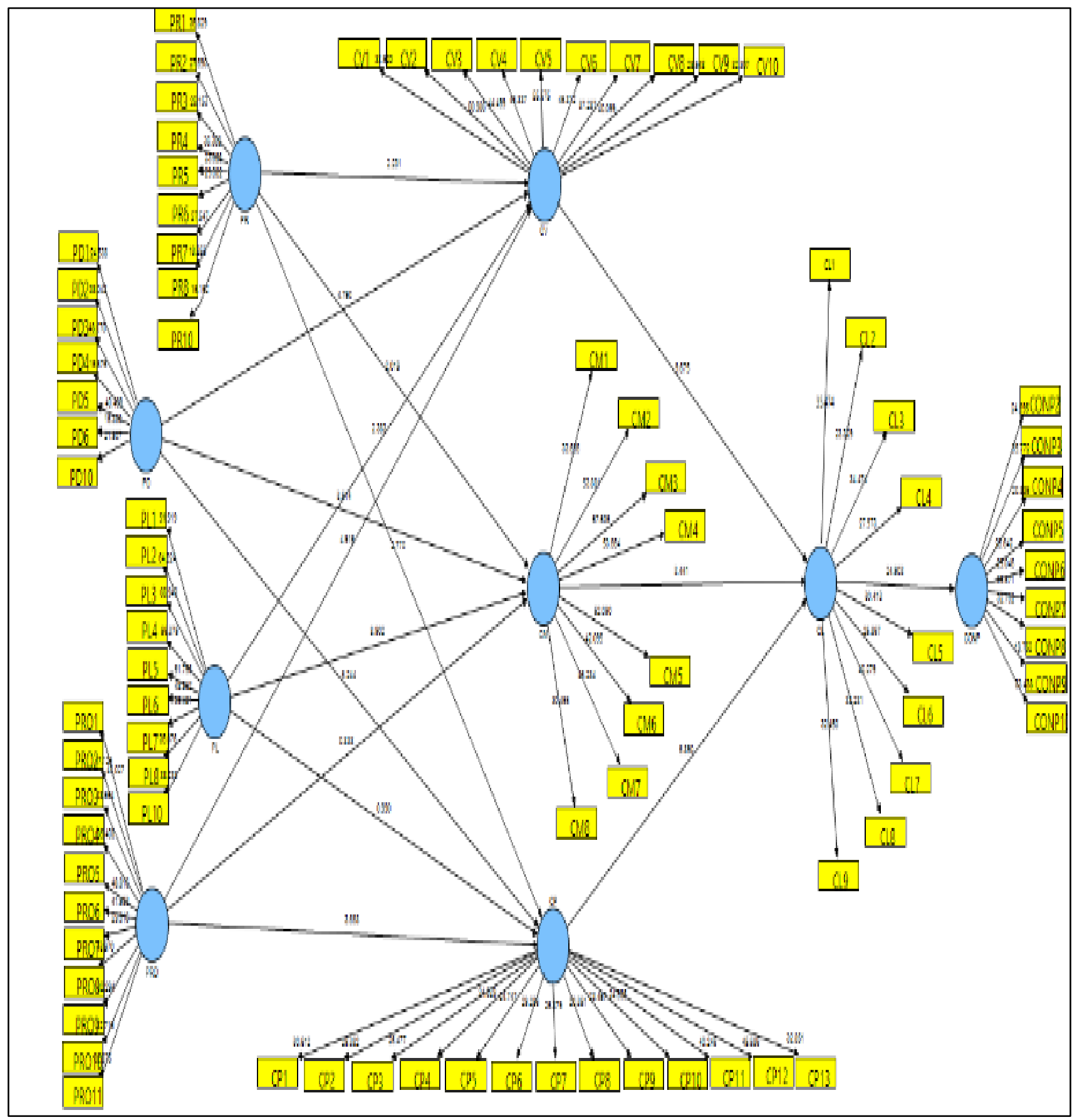




\subsection{Findings for hypotheses testing of direct relationship}

All 16 hypotheses were analysed by using SMARTPLS 2.0 program. Hair et. al (2006) [53] stated that T-value must be greater or equal to 1.645 for an alpha level of 0.05 to be accepted. 15 hypotheses were accepted and only one hypothesis rejected which is H6d, the relationship between marketing mix of promotion and consumer motive as shown in Table 4.4.

Below are the statements of hypotheses for direct relationship of consumption pattern model;

H1: Consumer life style is a direct predictor of consumption pattern.

$\mathrm{H} 2$ : Consumer value is a direct predictor of consumer life style.

H3: Consumer motive is a direct predictor of consumer life style.

H4: Consumer preference is a direct predictor of consumer life style.

H5a: Price is direct predictor of consumer value.

H5b: Product is a direct predictor of consumer value.

H5c: Place is a direct predictor of consumer value.

H5d: Promotion is a direct predictor of consumer value.

H6a: Price is direct predictor of consumer motive.

H6b: Product is a direct predictor of consumer motive.

H6c: Place is a direct predictor of consumer motive.

H6d: Promotion is a direct predictor of consumer motive.

$\mathrm{H7a}$ : Price is direct predictor of consumer preference.

$\mathrm{H} 7 \mathrm{~b}$ : Product is a direct predictor of consumer preference.

$\mathrm{H} 7 \mathrm{c}$ : Place is a direct predictor of consumer preference.
H7d: Promotion is a direct predictor of

\begin{tabular}{|c|c|c|c|c|c|}
\hline \multicolumn{3}{|c|}{$\begin{array}{l}\text { consumer } \\
\text { Hypotheses Relationship }\end{array}$} & \multicolumn{3}{|c|}{ preference. } \\
\hline & Relationship & $\begin{array}{c}\text { Path } \\
\text { coefficient }\end{array}$ & Std. Error & T-value & Decision \\
\hline HI & $\mathrm{CL} \rightarrow \mathrm{CONP}$ & 0.693 & 0.021 & $32.390^{* * *}$ & Supported \\
\hline $\mathrm{H}_{2}$ & $\mathrm{CV} \rightarrow \mathrm{CL}$ & 0.430 & 0.035 & $12.376^{* * *}$ & Supported \\
\hline $\mathrm{H} 3$ & $\mathrm{CM} \rightarrow \mathrm{CL}$ & 0.297 & 0.036 & $8.226^{6 * *}$ & Supported \\
\hline H4 & $\mathrm{CP} \rightarrow \mathrm{CL}$ & 0.161 & 0.038 & $4.267^{* * *}$ & Supported \\
\hline H5a & $\mathrm{PR} \rightarrow \mathrm{CV}$ & 0.135 & 0.044 & $3.068^{* * *}$ & Supported \\
\hline H5b & $\mathrm{PD} \rightarrow \mathrm{CV}$ & 0.304 & 0.045 & $6.722^{2 * *}$ & Supported \\
\hline $\mathrm{H} 5 \mathrm{c}$ & $\mathrm{PL} \rightarrow \mathrm{CV}$ & 0.130 & 0.047 & $2.739 * * *$ & Supported \\
\hline $\mathrm{H} 5 \mathrm{~d}$ & $\mathrm{PRO} \rightarrow \mathrm{CV}$ & 0.295 & 0.055 & $5.362^{2 * *}$ & Supported \\
\hline H6a & $\mathrm{PR} \rightarrow \mathrm{CM}$ & 0.145 & 0.052 & $2.769^{* * *}$ & Supported \\
\hline H6b & $\mathrm{PD} \rightarrow \mathrm{CM}$ & 0.254 & 0.047 & $5.366 * * *$ & Supported \\
\hline H6c & $\mathrm{PL} \rightarrow \mathrm{CM}$ & 0.399 & 0.039 & $10.219 * * *$ & Supported \\
\hline H6d & $\mathrm{PRO} \rightarrow \mathrm{CM}$ & 0.066 & 0.051 & 1.300 & Not supported \\
\hline $\mathrm{H} 7 \mathrm{a}$ & $\mathrm{PR} \rightarrow \mathrm{CP}$ & 0.165 & 0.047 & $3.472^{2 * * *}$ & Supported \\
\hline $\mathrm{H} 7 \mathrm{~b}$ & $\mathrm{PD} \rightarrow \mathrm{CP}$ & 0.383 & 0.050 & $7.597 * * *$ & Supported \\
\hline $\mathrm{H} 7 \mathrm{c}$ & $\mathrm{PL} \rightarrow \mathrm{CP}$ & 0.079 & 0.047 & $1.679 *$ & Supported \\
\hline H7d & $\mathrm{PRO} \rightarrow \mathrm{CP}$ & 0.226 & 0.047 & $4.768^{* * *}$ & Supported \\
\hline
\end{tabular}

Table 4.4

Hypotheses testing of direct relationship for consumption pattern model

Note. ${ }^{* * *} \mathrm{p}<0.001 ; * * \mathrm{p}<0.01 ; * \mathrm{p}<0.05$.

Consumption Pattern (CONP), Consumer Lifestyle (CL), Consumer Value (CV), Consumer Motive (CM), Consumer Preference (CP), Product (PD), Place (PL), Pricing (PR), and Promotion (PRO)

Results indicates that consumer lifestyle has a positive significant and direct predictor of consumption pattern $(\beta=0.693, \quad t=32.390$, $\mathrm{p}=0.000)$. Therefore, $\mathrm{H} 1$ are supported. On the other hand, consumer value $(\beta=0.430$, $\mathrm{t}=12.376, \quad \mathrm{p}=0.000)$, consumer motive $(\beta=0.297, t=8.226, p=0.000)$ and consumer preference $(\beta=0.161, t=4.267, p=0.000)$ have a positively significant on consumer lifestyle, thus, $\mathrm{H} 2, \mathrm{H} 3$, and $\mathrm{H} 4$ are supported. Besides, marketing mix has mixed results on consumer value. Price $(\beta=0.135, \mathrm{t}=3.068, \mathrm{p}=0.012)$, product $(\beta=0.304, \mathrm{t}=6.722, \mathrm{p}=0.000)$, place $(\beta=0.130, t=2.739, p=0.009)$ and promotion $(\beta=0.295, \mathrm{t}=5.362, \mathrm{p}=0.000)$ was a positive and direct predictor of consumer value. Therefore, $\mathrm{H} 5 \mathrm{a}, \mathrm{H} 5 \mathrm{~b}, \mathrm{H} 5 \mathrm{c}$ and $\mathrm{H} 5 \mathrm{~d}$ are supported. Price $(\beta=0.145, t=2.769, p=0.000)$, product $(\beta=0.254$, $\mathrm{t}=5.366, \quad \mathrm{p}=0.000)$ and place $(\beta=0.399$, 
$\mathrm{t}=10.219, \quad \mathrm{p}=0.000)$ have a positively significant and direct predictor of consumer motive. However, promotion $(\beta=0.066$, $\mathrm{t}=1.300, \mathrm{p}>0.000)$ did not significant with consumer motive. Therefore, H6a, H6b and H6c are supported, while, the result of H6d is not supported and was rejected.

On the contrary, all the predictor of marketing mix was positively significant with customer preference where, price $(\beta=0.165, \mathrm{t}=3.472$, $\mathrm{p}=0.000)$, product $(\beta=0.383, \mathrm{t}=7.597, \mathrm{p}=0.000)$, place $(\beta=0.079, \quad \mathrm{t}=1.679, \quad \mathrm{p}<0.050) \quad$ and promotion $(\beta=0.215, \quad \mathrm{t}=3.721, \quad \mathrm{p}=0.000)$. Findings also revealed only place is significant at $\mathrm{P}$ value less than 0.05 . Hence, $\mathrm{H} 7 \mathrm{a}, \mathrm{H} 7 \mathrm{~b}, \mathrm{H} 7 \mathrm{c}$ and $\mathrm{H} 7 \mathrm{~d}$ were supported.

\subsubsection{Findings for hypotheses testing for mediating effect: Consumer lifestyle as a mediator in consumption pattern model.}

The bootstrapping results shows that consumer lifestyle is the mediator of the relationship between consumer value and consumption pattern $\quad(\beta=0.307, \quad \mathrm{t}=11.371, \quad \mathrm{p}=0.000)$, consumer motive and consumption pattern $(\beta=0.331, t=12.272, p=0.000)$, and consumer preference and consumption pattern $(\beta=0.339$, $\mathrm{t}=13.566, \mathrm{p}=0.000)$ as postulated in table 4.5 below. Findings showed all mediator were supported. Thus, $\mathrm{H} 8 \mathrm{a}, \mathrm{H} 8 \mathrm{~b}$ and $\mathrm{H} 8 \mathrm{c}$ were accepted.

\begin{tabular}{|c|c|c|c|c|c|c|c|c|c|c|}
\hline Hypotheses & $\begin{array}{l}\text { Hypotheses } \\
\text { Path }\end{array}$ & $\begin{array}{l}\text { Path } \\
\text { A }\end{array}$ & $\begin{array}{l}\text { Path } \\
\text { b }\end{array}$ & $\begin{array}{l}\text { Path } \\
\text { c }\end{array}$ & $\begin{array}{l}\text { Indirec } \\
\text { Effect }\end{array}$ & $\begin{array}{l}\text { Std. } \\
\text { Error }\end{array}$ & $\begin{array}{l}\text { T- } \\
\text { value }\end{array}$ & $95 \%$ LL & $\begin{array}{l}95 \% \\
\text { UL }\end{array}$ & Decision \\
\hline
\end{tabular}

Table 4.5

The mediating effect of consumer lifestyle for consumption pattern model

\begin{tabular}{|c|c|c|c|c|c|c|c|c|c|}
\hline Hypotheses & Hypotheses Path & $\begin{array}{l}\text { Path } \\
\text { a }\end{array}$ & $\begin{array}{l}\text { Path } \\
\text { b }\end{array}$ & $\begin{array}{l}\text { Indirect } \\
\text { Effect }\end{array}$ & $\begin{array}{l}\text { Std. } \\
\text { Error }\end{array}$ & T-value & $\begin{array}{l}95 \% \\
\text { LL }\end{array}$ & $\begin{array}{l}95 \% \\
\text { UL }\end{array}$ & Decision \\
\hline \multirow[t]{2}{*}{ H8a } & $\mathrm{CV}->\mathrm{CL}->\mathrm{CONP}$ & 0.714 & 0.430 & 0.307 & 0.027 & 11.371 & 0.254 & 0.360 & $\begin{array}{l}\text { Mediate } \\
\text { Mediate }\end{array}$ \\
\hline & $\mathrm{CM}->\mathrm{CL}->\mathrm{CONP}$ & & & & & & & & \\
\hline $\mathrm{H} 8 \mathrm{~b}$ & & 0.624 & 0.531 & 0.331 & 0.027 & 12.272 & 0.278 & 0.384 & Modinto \\
\hline $\mathrm{H} 8 \mathrm{c}$ & $\mathrm{CP}->\mathrm{CL}->\mathrm{CONP}$ & 0.656 & 0.517 & 0.339 & 0.025 & 13.566 & 0.290 & 0.388 & \\
\hline
\end{tabular}




\subsubsection{The hypotheses testing for mediating effect: Consumer value, consumer motive and consumer preference.}

Results indicate that consumer value mediates the relationship marketing mix (price, product, place and promotion), consumer lifestyle and consumption pattern. Bootstrapping results indicate that consumer value is the mediator of the relationship between price, consumer lifestyle and consumption pattern $(\beta=0.098, \mathrm{t}=6.984, \mathrm{p}=0.000)$, a mediator in relationship between product, consumer lifestyle and consumption pattern $(\beta=0.126$, $\mathrm{t}=9.006, \mathrm{p}=0.000)$, a mediator in relationship between place, consumer lifestyle and consumption pattern $(\beta=0.148, \mathrm{t}=9.856, \mathrm{p}=0.000)$, also a mediator in relationship between promotion, consumer lifestyle and consumption pattern $(\beta=0.117, t=8.323, p=0.000)$. Therefore, H9a, H9b, $\mathrm{H} 9 \mathrm{c}$ and H9d were accepted.

Bootstrapping results also show that consumer motive mediates the relationship between price, consumer lifestyle and consumption pattern $(\beta=0.082, \quad \mathrm{t}=4.297, \quad \mathrm{p}=0.000), \quad$ mediates the relationship between product, consumer lifestyle and consumption pattern $(\beta=0.099$, $\mathrm{t}=12.367, \mathrm{p}=0.000$ ), mediates the relationship between place, consumer lifestyle and consumption pattern $(\beta=0.156, t=17.315, p=0.000)$, and mediates the relationship between promotion, consumer lifestyle and consumption pattern $(\beta=0.085$, $\mathrm{t}=7.772, \quad \mathrm{p}=0.000$ ). Hence, as result of bootstrapping supported consumer motive as a mediator in this model, H10a, H10b, H10c and H10d were accepted.

Additionally, results of bootstrapping indicates consumer preference also mediates the relationship between price, consumer lifestyle and consumption pattern $(\beta=0.095, t=7.910, p=0.000)$, mediates the relationship between product, consumer lifestyle and consumption pattern $(\beta=0.118, \mathrm{t}=9.086$, $\mathrm{p}=0.000$ ), mediates the relationship between place, consumer lifestyle and consumption pattern $(\beta=0.140, \mathrm{t}=14.050, \mathrm{p}=0.000)$, and mediates the relationship between promotion, consumer lifestyle and consumption pattern $(\beta=0.109, \quad \mathrm{t}=9.112$, $\mathrm{p}=0.000)$. Thus, as result of bootstrapping supported consumer motive as a mediator in this model, H1 1a, H1 1b, H11c and H11d were accepted.

\begin{tabular}{|c|c|c|c|c|c|c|c|c|c|c|}
\hline $\mathrm{H} 9 \mathrm{a}$ & $\mathrm{PR} \rightarrow \mathrm{CV} \rightarrow \mathrm{CL} \rightarrow \mathrm{CONP}$ & 0.643 & 0.458 & 0.332 & 0.098 & 0.014 & 6.984 & 0.070 & 0.125 & Mediate \\
\hline $\mathrm{H} 9 \mathrm{~b}$ & $\mathrm{PD} \rightarrow \mathrm{CV} \rightarrow \mathrm{CL} \rightarrow \mathrm{CONP}$ & 0.695 & 0.489 & 0.371 & 0.126 & 0.015 & 9.006 & 0.099 & 0.154 & Mediate \\
\hline $\mathrm{H} 9 \mathrm{c}$ & $\mathrm{PL} \rightarrow \mathrm{CV} \rightarrow \mathrm{CL} \rightarrow \mathrm{CONP}$ & 0.626 & 0.576 & 0.410 & 0.148 & 0.014 & 9.856 & 0.118 & 0.177 & Mediate \\
\hline H9d & $\mathrm{PRO} \rightarrow \mathrm{CV} \rightarrow \mathrm{CL} \rightarrow \mathrm{CONP}$ & 0.693 & 0.452 & 0.372 & 0.117 & 0.019 & 8.323 & 0.089 & 0.144 & Mediate \\
\hline H10a & $\mathrm{PR} \rightarrow \mathrm{CM} \rightarrow \mathrm{CL} \rightarrow \mathrm{CONP}$ & 0.621 & 0.313 & 0.420 & 0.082 & 0.008 & 4.297 & 0.044 & 0.119 & Mediate \\
\hline $\mathrm{H} 10 \mathrm{~b}$ & $\mathrm{PD} \rightarrow \mathrm{CM} \rightarrow \mathrm{CL} \rightarrow \mathrm{CONP}$ & 0.675 & 0.325 & 0.451 & 0.099 & 0.009 & 12.367 & 0.083 & 0.115 & Mediate \\
\hline $\mathrm{H} 10 \mathrm{c}$ & $\mathrm{PL} \rightarrow \mathrm{CM} \rightarrow \mathrm{CL} \rightarrow \mathrm{CONP}$ & 0.712 & 0.425 & 0.515 & 0.156 & 0.011 & 17.315 & 0.138 & 0.173 & Mediate \\
\hline H10d & $\mathrm{PRO} \rightarrow \mathrm{CM} \rightarrow \mathrm{CL} \rightarrow \mathrm{CONP}$ & 0.618 & 0.318 & 0.435 & 0.085 & 0.006 & 7.772 & 0.064 & 0.107 & Mediate \\
\hline H11a & $\mathrm{PR} \rightarrow \mathrm{CP} \rightarrow \mathrm{CL} \rightarrow \mathrm{CONP}$ & 0.644 & 0.356 & 0.414 & 0.095 & 0.012 & 7.910 & 0.071 & 0.118 & Mediate \\
\hline $\mathrm{H} 11 \mathrm{~b}$ & $\mathrm{PD} \rightarrow \mathrm{CP} \rightarrow \mathrm{CL} \rightarrow \mathrm{CONP}$ & 0.711 & 0.370 & 0.449 & 0.118 & 0.013 & 9.086 & 0.093 & 0.144 & Mediate \\
\hline $\mathrm{H} 11 \mathrm{c}$ & $\mathrm{PL} \rightarrow \mathrm{CP} \rightarrow \mathrm{CL} \rightarrow \mathrm{CONP}$ & 0.606 & 0.480 & 0.483 & 0.140 & 0.010 & 14.050 & 0.121 & 0.160 & Mediate \\
\hline H11d & $\mathrm{PRO} \rightarrow \mathrm{CP} \rightarrow \mathrm{CL} \rightarrow \mathrm{CONP}$ & 0.666 & 0.374 & 0.439 & 0.109 & 0.012 & 9.112 & 0.086 & 0.133 & Mediate \\
\hline
\end{tabular}

The mediatingct of consumer value, consumer motive and consumer preference for consumption pattern model.Note. LL-Lower limit, UL-Upper limit. Consumer Lifestyle (CL), Consumer Value (CV), Consumer Motive (CM), Consumer Preference (CP), Product (PD),Place (PL), Pricing (PR), and Promotion (PRO). 


\subsection{Consumption pattern model for rural area}

In this section, the discussion of findings was narrowed down to the consumption pattern model for rural area. All 16 hypotheses were analysed by using SMARTPLS 2.0 program. [43] stated that Tvalue must be greater or equal to 1.645 for an alpha level of 0.05 to be accepted. 14 hypotheses were accepted and two hypothesis H6a and H6d are not supported and were rejected. Table 4.7.

Below are the statements of hypotheses for direct relationship of consumption pattern model in rural area;

H1 : Consumer life style is a direct predictor of consumption pattern in rural area.

H2 : Consumer value is a direct predictor of consumer life style.

H3 : Consumer motive is a direct predictor of consumer life style.

H4 : Consumer preference is a direct predictor of consumer life style.
H5a : Price is direct predictor of consumer value.

$\mathrm{H} 5 \mathrm{~b}$ : Product is a direct predictor of consumer value.

H5c : Place is a direct predictor of consumer value.

H5d : Promotion is a direct predictor of consumer value.

H6a : Price is direct predictor of consumer motive.

$\mathrm{H} 6 \mathrm{~b}$ : $\quad$ Product is a direct predictor of consumer motive.

H6c : Place is a direct predictor of consumer motive.

H6d : $\quad$ Promotion is a direct predictor of consumer motive.

$\mathrm{H7a}$ : Price is direct predictor of consumer preference.

$\mathrm{H} 7 \mathrm{~b}$ : Product is a direct predictor of consumer preference.

$\mathrm{H7c}$ : Place is a direct predictor of consumer preference.

H7d : Promotion is a direct predictor of consumer preference.

Table 4.7

Hypotheses Testing of direct relationship for consumption pattern model in rural area

\begin{tabular}{llllll}
\hline Hypotheses & Relationship & $\begin{array}{l}\text { Path } \\
\text { coefficient }\end{array}$ & Std. Error & T-value & Decision \\
\hline HI & CL $\rightarrow$ CONP & 0.711 & 0.034 & $20.855^{* * *}$ & Supported \\
H2 & CV $\rightarrow$ CL & 0.427 & 0.060 & $7.079^{* * *}$ & Supported \\
H3 & CM $\rightarrow$ CL & 0.192 & 0.066 & $2.888^{* * *}$ & Supported \\
H4 & CP $\rightarrow$ CL & 0.266 & 0.063 & $4.241^{* * *}$ & Supported \\
H5a & PR $\rightarrow$ CV & 0.170 & 0.072 & $2.362^{* *}$ & Supported \\
H5b & PD $\rightarrow$ CV & 0.350 & 0.069 & $5.050^{* * *}$ & Supported \\
H5c & PL $\rightarrow$ CV & 0.138 & 0.075 & $1.843^{*}$ & Supported \\
H5d & PRO $\rightarrow$ CV & 0.206 & 0.080 & $2.595^{* *}$ & Supported \\
H6a & PR $\rightarrow$ CM & $\mathbf{0 . 1 0 7}$ & $\mathbf{0 . 0 9 0}$ & $\mathbf{1 . 1 9 6}$ & Not Supported \\
H6b & PD $\rightarrow$ CM & 0.352 & 0.074 & $4.745^{* * *}$ & Supported \\
H6c & PL $\rightarrow$ CM & 0.318 & 0.060 & $5.292^{* * *}$ & Supported \\
H6d & PRO $\rightarrow$ CM & $\mathbf{0 . 1 2 0}$ & $\mathbf{0 . 0 8 6}$ & $\mathbf{1 . 3 8 5}$ & Not supported \\
H7a & PR $\rightarrow$ CP & 0.165 & 0.072 & $2.285^{*}$ & Supported \\
H7b & PD $\rightarrow$ CP & 0.396 & 0.083 & $4.798^{* * *}$ & Supported \\
H7c & PL $\rightarrow$ CP & 0.151 & 0.081 & $1.863^{*}$ & Supported \\
H7d & PRO $\rightarrow$ CP & 0.179 & 0.085 & $2.123^{*}$ & Supported \\
\hline
\end{tabular}

Note. ${ }^{* *} \mathrm{p}<0.001 ; * * \mathrm{p}<0.01 ; * \mathrm{p}<0.05$. Consumption Pattern (CONP), Consumer Lifestyle (CL), Consumer Value (CV), Consumer Motive (CM), Consumer Preference (CP), Product (PD), Place (PL), Pricing (PR), and Promotion (PRO) 
Results indicates consumer lifestyle has a positive significant and direct predictor of consumption pattern in rural area $(\beta=0.711$, $\mathrm{t}=20.855, \quad \mathrm{p}<0.001)$. Therefore, $\mathrm{H} 1 \mathrm{are}$ supported. On the other hand, consumer value $(\beta=0.427, t=7.079, p<0.001)$, consumer motive $(\beta=0.192, \mathrm{t}=2.888, \mathrm{p}<0.001)$ and consumer preference $(\beta=0.266, t=4.241, p<0.001)$ have a positively significant on consumer lifestyle, thus, H2, H3, and H4 are supported. Besides, marketing mix has mixed results on consumer value. Price $(\beta=0.170, \mathrm{t}=2.362, \mathrm{p}<0.01)$, product $(\beta=0.350, \mathrm{t}=5.050, \mathrm{p}<0.001)$, place $(\beta=0.138, \mathrm{t}=1.843, \mathrm{p}<0.05)$ and promotion $(\beta=0.206, t=2.595, p<0.01)$ was a positive and direct predictor of consumer value. Therefore, $\mathrm{H} 5 \mathrm{a}, \mathrm{H} 5 \mathrm{~b}, \mathrm{H} 5 \mathrm{c}$ and $\mathrm{H} 5 \mathrm{~d}$ are supported. Product $(\beta=0.352, \quad \mathrm{t}=4.745, \quad \mathrm{p}<0.001) \quad$ and place $(\beta=0.318, t=5.292, p<0.001)$ have a positively significant and direct predictor of consumer motive. However, price $(\beta=0.107, \mathrm{t}=1.196$, $\mathrm{p}>0.05)$ and promotion $(\beta=0.120, \mathrm{t}=1.385$, $p>0.05$ ) did not significant with consumer motive. Therefore, H6b and H6c are supported, while, the result of H6a and H6d are not supported and were rejected. On the contrary, all the predictor of marketing mix was positively significant with customer preference where, price $(\beta=0.165, \mathrm{t}=2.285, \quad \mathrm{p}<0.05)$, product $(\beta=0.396, \mathrm{t}=4.798, \mathrm{p}<0.001)$, place $(\beta=0.151, \mathrm{t}=1.863, \mathrm{p}<0.05)$ and promotion $(\beta=0.179, \mathrm{t}=2.123, \mathrm{p}<0.05)$. Findings also revealed only product is significant at $\mathrm{P}$ value less than 0.001. Meanwhile for price, place and promotion were significant at $\mathrm{p}$ value less than 0.05. Hence, H7a, H7b, H7c and H7d were supported.

\subsubsection{The hypotheses testing for mediating effect: Consumer lifestyle as a mediator in rural area.}

The bootstrapping results show that the consumer lifestyle is the mediator of the relationship between consumer value and consumption pattern

$(\beta=0.344, \quad t=7.808, \quad p=0.000), \quad$ consumer motive and consumption pattern $(\beta=0.328$, $\mathrm{t}=6.686, \mathrm{p}=0.000)$, and consumer preference and consumption pattern $(\beta=0.314, \mathrm{t}=6.674$, $\mathrm{p}=0.000$ ) aspostulated in table 4.17 below. Findings showed all mediator were supported. Thus, H8a, H8b and H8c were accepted

Table 4.8

The mediating effect of consumer lifestyle for consumption pattern model.

\begin{tabular}{|c|c|c|c|c|c|c|c|c|c|}
\hline Hypotheses & Hypotheses Path & $\begin{array}{l}\text { Path } \\
\text { a }\end{array}$ & $\begin{array}{l}\text { Path } \\
\text { b }\end{array}$ & $\begin{array}{l}\text { Indirect } \\
\text { Effect }\end{array}$ & $\begin{array}{l}\text { Std. } \\
\text { Error }\end{array}$ & $\begin{array}{l}\text { T- } \\
\text { value }\end{array}$ & $\begin{array}{l}95 \% \\
\text { LL }\end{array}$ & $\begin{array}{l}95 \% \\
\text { UL }\end{array}$ & Decision \\
\hline \multirow[t]{3}{*}{$\mathrm{H} 8 \mathrm{a}$} & $\mathrm{CV}->\mathrm{CL}->\mathrm{CONP}$ & 0.742 & 0.463 & 0.344 & 0.044 & 7.808 & 0.257 & 0.430 & Mediate \\
\hline & & 0.697 & 0.470 & 0.328 & 0.049 & 6.686 & 0.232 & 0.424 & Mediate \\
\hline & $\mathrm{CM}->\mathrm{CL}->\mathrm{CONP}$ & & & & & & & & \\
\hline \multicolumn{10}{|l|}{$\mathrm{H} 8 \mathrm{~b}$} \\
\hline $\mathrm{H} 8 \mathrm{c}$ & $\mathrm{CP}->\mathrm{CL}->\mathrm{CONP}$ & 0.676 & 0.464 & 0.314 & 0.047 & 6.674 & 0.222 & 0.406 & Mediate \\
\hline
\end{tabular}


4.4.2 The hypotheses testing for mediating effect: Consumer value, consumer motive and consumer preference as a mediator in rural area.

Consumer value, consumer motive and consumer preference were mediator for the relationship marketing mix (price, product, place and promotion), consumer lifestyle and consumption pattern. Bootstrapping results indicate that consumer value is the mediator of the relationship between price, consumer lifestyle and consumption pattern $(\beta=0.090$, $\mathrm{t}=3.733, \mathrm{p}=0.000$ ), a mediator in relationship between product, consumer lifestyle and consumption pattern $(\beta=0.121, \quad \mathrm{t}=5.049$, $\mathrm{p}=0.000$ ), a mediator in relationship between place, consumer lifestyle and consumption pattern $(\beta=0.162, \mathrm{t}=5.778, \mathrm{p}=0.000)$, also a mediator in relationship between promotion, consumer lifestyle and consumption pattern $(\beta=0.127, \quad t=5.525, \quad p=0.000)$. The findings indicated consumer value mediates the relationship marketing mix (price, product, place and promotion), consumer lifestyle and consumption pattern. Therefore, we accept H9a, H9b, H9c and H9d. Table 4.9 below indicated mediating results for construct consumer value, consumer motive and consumer preference.

Table 4.9

The mediating effect of consumer value, consumer motive and consumer preference for consumption pattern model.

\begin{tabular}{|c|c|c|c|c|c|c|c|c|c|c|}
\hline $\begin{array}{l}\text { Hypothese } \\
\text { s }\end{array}$ & Hypotheses Path & $\begin{array}{l}\text { Path } \\
\text { A }\end{array}$ & $\begin{array}{l}\text { Path } \\
\text { b }\end{array}$ & $\begin{array}{l}\text { Path } \\
\text { c }\end{array}$ & $\begin{array}{l}\text { Indirect } \\
\text { Effect }\end{array}$ & $\begin{array}{l}\text { Std. } \\
\text { Error }\end{array}$ & $\begin{array}{l}\text { T- } \\
\text { value }\end{array}$ & $\begin{array}{l}95 \% \\
\text { LL }\end{array}$ & $\begin{array}{l}95 \% \\
\text { UL } \\
\end{array}$ & Decision \\
\hline H9a & $\begin{array}{l}\mathrm{PR} \rightarrow \mathrm{CV} \rightarrow \mathrm{CL} \rightarrow \\
\mathrm{CONP}\end{array}$ & 0.668 & 0.469 & $\begin{array}{l}0.28 \\
6\end{array}$ & 0.090 & 0.024 & 3.733 & $\begin{array}{l}0.04 \\
3\end{array}$ & 0.137 & Mediate \\
\hline $\mathrm{H} 9 \mathrm{~b}$ & $\begin{array}{l}\mathrm{PD} \rightarrow \mathrm{CV} \rightarrow \mathrm{CL} \rightarrow \\
\mathrm{CONP}\end{array}$ & 0.719 & 0.458 & $\begin{array}{l}0.36 \\
8\end{array}$ & 0.121 & 0.028 & 5.049 & $\begin{array}{l}0.07 \\
4\end{array}$ & 0.168 & Mediate \\
\hline H9c & $\begin{array}{l}\mathrm{PL} \rightarrow \mathrm{CV} \rightarrow \mathrm{CL} \rightarrow \\
\mathrm{CONP}\end{array}$ & 0.642 & 0.574 & $\begin{array}{l}0.43 \\
9\end{array}$ & 0.162 & 0.023 & 5.778 & $\begin{array}{l}0.10 \\
7\end{array}$ & 0.217 & Mediate \\
\hline H9d & $\begin{array}{l}\mathrm{PRO} \rightarrow \mathrm{CV} \rightarrow \mathrm{CL} \\
\rightarrow \mathrm{CONP}\end{array}$ & 0.697 & 0.476 & $\begin{array}{l}0.38 \\
3\end{array}$ & 0.127 & 0.027 & 5.525 & $\begin{array}{l}0.08 \\
2\end{array}$ & 0.172 & Mediate \\
\hline $\mathrm{H} 10 \mathrm{a}$ & $\begin{array}{l}\mathrm{PR} \rightarrow \mathrm{CM} \rightarrow \mathrm{CL} \rightarrow \\
\mathrm{CONP}\end{array}$ & 0.650 & 0.393 & $\begin{array}{l}0.29 \\
1\end{array}$ & 0.074 & 0.015 & 2.753 & $\begin{array}{l}0.02 \\
1\end{array}$ & 0.127 & Mediate \\
\hline $\mathrm{H} 10 \mathrm{~b}$ & $\begin{array}{l}\mathrm{PD} \rightarrow \mathrm{CM} \rightarrow \mathrm{CL} \rightarrow \\
\mathrm{CONP}\end{array}$ & 0.737 & 0.358 & $\begin{array}{l}0.39 \\
2\end{array}$ & 0.103 & 0.020 & 6.895 & $\begin{array}{l}0.07 \\
4\end{array}$ & 0.133 & Mediate \\
\hline H10c & $\begin{array}{l}\mathrm{PL} \rightarrow \mathrm{CM} \rightarrow \mathrm{CL} \rightarrow \\
\mathrm{CONP}\end{array}$ & 0.721 & 0.503 & $\begin{array}{l}0.46 \\
8\end{array}$ & 0.170 & 0.017 & 8.486 & $\begin{array}{l}0.13 \\
1\end{array}$ & 0.209 & Mediate \\
\hline H10d & $\begin{array}{l}\mathrm{PRO} \rightarrow \mathrm{CM} \rightarrow \mathrm{CL} \\
\rightarrow \mathrm{CONP}\end{array}$ & 0.695 & 0.390 & $\begin{array}{l}0.39 \\
6\end{array}$ & 0.107 & 0.014 & 6.314 & $\begin{array}{l}0.07 \\
4\end{array}$ & 0.141 & Mediate \\
\hline H11a & $\begin{array}{l}\mathrm{PR} \rightarrow \mathrm{CP} \rightarrow \mathrm{CL} \rightarrow \\
\mathrm{CONP}\end{array}$ & 0.683 & 0.342 & $\begin{array}{l}0.31 \\
6\end{array}$ & 0.074 & 0.017 & 4.342 & $\begin{array}{l}0.04 \\
0\end{array}$ & 0.107 & Mediate \\
\hline H11b & $\begin{array}{l}\mathrm{PD} \rightarrow \mathrm{CP} \rightarrow \mathrm{CL} \rightarrow \\
\mathrm{CONP}\end{array}$ & 0.752 & 0.302 & $\begin{array}{l}0.40 \\
1\end{array}$ & 0.091 & 0.023 & 3.960 & $\begin{array}{l}0.04 \\
6\end{array}$ & 0.136 & Mediate \\
\hline H11c & $\begin{array}{l}\mathrm{PL} \rightarrow \mathrm{CP} \rightarrow \mathrm{CL} \rightarrow \\
\mathrm{CONP}\end{array}$ & 0.644 & 0.459 & $\begin{array}{l}0.46 \\
0\end{array}$ & 0.136 & 0.016 & 8.498 & $\begin{array}{l}0.10 \\
5\end{array}$ & 0.167 & Mediate \\
\hline H11d & $\begin{array}{l}\mathrm{PRO} \rightarrow \mathrm{CP} \rightarrow \mathrm{CL} \\
\rightarrow \mathrm{CONP}\end{array}$ & 0.709 & 0.341 & $\begin{array}{l}0.40 \\
9\end{array}$ & 0.099 & 0.020 & 4.944 & $\begin{array}{l}0.06 \\
0\end{array}$ & 0.138 & Mediate \\
\hline
\end{tabular}

Note. LL-Lower limit, UL-Upper limit. Consumer Lifestyle (CL), Consumer Value (CV), Consumer Motive (CM), Consumer Preference (CP), Product (PD), Place (PL), Pricing (PR), and Promotion (PRO). 
Bootstrapping results also show that consumer motive mediates the relationship between price, consumer lifestyle and consumption pattern $(\beta=0.074, \quad \mathrm{t}=2.753, \quad \mathrm{p}=0.000)$, mediates the relationship between product, consumer lifestyle and consumption pattern $(\beta=0.103, \mathrm{t}=6.895$, Hence, bootstrapping supported consumer motive as a mediator in the consumption pattern model for rural area, H10a, H10b, H10c and H10d were accepted.

In addition, results of bootstrapping indicates consumer preference also mediates the relationship between price, consumer lifestyle and consumption pattern $(\beta=0.074, t=4.342, p=0.000)$, mediates the relationship between product, consumer lifestyle and consumption pattern $(\beta=0.118, \mathrm{t}=9.086, \quad \mathrm{p}=0.000)$, mediates the relationship between place, consumer lifestyle and consumption pattern $(\beta=0.091, \mathrm{t}=3.960$, $\mathrm{p}=0.000$ ), and mediates the relationship between promotion, consumer lifestyle and consumption pattern $(\beta=0.099, \mathrm{t}=4.944, \mathrm{p}=0.000)$. Thus, as result of bootstrapping supported consumer motive as a mediator in the consumption pattern model for rural area, H11a, H11b, H1 1c and H11d were accepted.

\subsection{Consumption pattern model for urban area}

In this section, the discussion of findings was narrowed down to the consumption pattern model for urban area. All 16 hypotheses were analysed by using SMARTPLS 2.0 program. [43] stated that T-value must be greater or equal to 1.645 for an alpha level of 0.05 to be accepted. 14 hypotheses were accepted and two hypothesis $\mathrm{H} 6 \mathrm{~d}$ and $\mathrm{H} 7 \mathrm{c}$ are not supported and were rejected as in Table 4.10. Below are the statements of hypotheses for direct relationship of consumption pattern model in urban area; $\mathrm{p}=0.000$ ), mediates the relationship between place, consumer lifestyle and consumption pattern $(\beta=0.170, t=8.486, p=0.000)$, and mediates the relationship between promotion, consumer lifestyle and consumption pattern $(\beta=0.107$, $\mathrm{t}=6.314, \mathrm{p}=0.000$ ).

H1 : Consumer life style is a direct predictor of consumption pattern in rural area.

$\mathrm{H} 2$ : Consumer value is a direct predictor of consumer life style.

H3 : Consumer motive is a direct predictor of consumer life style.

$\mathrm{H} 4$ : $\quad$ Consumer preference is a direct predictor of consumer life style.

$\mathrm{H} 5 \mathrm{a}$ : Price is direct predictor of consumer value.

$\mathrm{H} 5 \mathrm{~b}$ : $\quad$ Product is a direct predictor of consumer value.

$\mathrm{H} 5 \mathrm{c}$ : Place is a direct predictor of consumer value.

H5d : Promotion is a direct predictor of consumer value.

H6a : Price is direct predictor of consumer motive.

$\mathrm{H} 6 \mathrm{~b}$ : $\quad$ Product is a direct predictor of consumer motive.

H6c : Place is a direct predictor of consumer motive.

H6d : Promotion is a direct predictor of consumer motive.

$\mathrm{H7a}$ : Price is direct predictor of consumer preference.

$\mathrm{H} 7 \mathrm{~b} \quad$ : $\quad$ Product is a direct predictor of consumer preference.

$\mathrm{H7c}$ : Place is a direct predictor of consumer preference.

H7d : $\quad$ Promotion is a direct predictor of consumer preference 
Table 4.10

Hypotheses Testing of direct relationship for consumption pattern model in rural area

\begin{tabular}{llllll}
\hline Hypotheses & Relationship & $\begin{array}{l}\text { Path } \\
\text { coefficient }\end{array}$ & Std. Error & T-value & Decision \\
\hline HI & CL $\rightarrow$ CONP & 0.678 & 0.028 & $24.265^{* * *}$ & Supported \\
H2 & CV $\rightarrow$ CL & 0.417 & 0.044 & $9.572^{* * *}$ & Supported \\
H3 & CM $\rightarrow$ CL & 0.158 & 0.047 & $3.352^{* * *}$ & Supported \\
H4 & CP $\rightarrow$ CL & 0.309 & 0.046 & $6.778^{* * *}$ & Supported \\
H5a & PR $\rightarrow$ CV & 0.157 & 0.052 & $3.036^{* * *}$ & Supported \\
H5b & PD $\rightarrow$ CV & 0.279 & 0.059 & $4.745^{* * *}$ & Supported \\
H5c & PL $\rightarrow$ CV & 0.131 & 0.059 & $2.231^{*}$ & Supported \\
H5d & PRO $\rightarrow$ CV & 0.302 & 0.065 & $4.657^{* * *}$ & Supported \\
H6a & PR $\rightarrow$ CM & 0.114 & 0.064 & $1.783^{*}$ & Supported \\
H6b & PD $\rightarrow$ CM & 0.222 & 0.062 & $3.594^{* * *}$ & Supported \\
H6c & PL $\rightarrow$ CM & 0.444 & 0.050 & $8.884^{* * *}$ & Supported \\
H6d & PRO $\rightarrow$ CM & $\mathbf{0 . 0 5 9}$ & $\mathbf{0 . 0 6 0}$ & $\mathbf{0 . 9 8 0}$ & Not supported \\
H7a & PR $\rightarrow$ CP & 0.151 & 0.062 & $2.450^{* *}$ & Supported \\
H7b & PD $\rightarrow$ CP & 0.395 & 0.064 & $6.195^{* * *}$ & Supported \\
H7c & PL $\rightarrow$ CP & $\mathbf{0 . 0 5 8}$ & $\mathbf{0 . 0 5 8}$ & $\mathbf{0 . 9 9 6}$ & Not Supported \\
H7d & PRO $\rightarrow$ CP & 0.227 & 0.058 & $3.903^{* * *}$ & Supported \\
\hline
\end{tabular}

Note. ${ }^{* * *} \mathrm{p}<0.001 ; * * \mathrm{p}<0.01 ; * \mathrm{p}<0.05$. Consumption Pattern (CONP), Consumer Lifestyle (CL), Consumer Value (CV), Consumer Motive (CM), Consumer Preference (CP), Product (PD), Place (PL), Pricing (PR), and Promotion (PRO)

Results show that consumer lifestyle has a positive significant and direct predictor of consumption pattern in rural area $(\beta=0.678$, $\mathrm{t}=24.265, \mathrm{p}<0.001)$. Therefore, $\mathrm{H} 1$ are supported. On the other hand, consumer value $(\beta=0.417$, $\mathrm{t}=9.572, p<0.001)$, consumer motive $(\beta=0.158$, $\mathrm{t}=3.352, \mathrm{p}<0.001)$ and consumer preference $(\beta=0.309, \mathrm{t}=6.678, \mathrm{p}<0.001)$ have a positively significant on consumer lifestyle, thus, H2, H3, and $\mathrm{H} 4$ are supported. Besides, marketing mix has mixed results of significance level on consumer value. Price $(\beta=0.157, t=3.036, p<0.01)$, product $(\beta=0.279, \mathrm{t}=4.745, \quad \mathrm{p}<0.001)$, place $(\beta=0.131$, $\mathrm{t}=2.231, \quad \mathrm{p}<0.05)$ and promotion $(\beta=0.302$, $\mathrm{t}=3.657, \mathrm{p}<0.01$ ) was a positive and 
direct predictor of consumer value. Therefore, $\mathrm{H} 5 \mathrm{a}, \mathrm{H} 5 \mathrm{~b}, \mathrm{H} 5 \mathrm{c}$ and $\mathrm{H} 5 \mathrm{~d}$ are supported.

In other findings, product $(\beta=0.114, \mathrm{t}=1.783$, $\mathrm{p}<0.001)$ and place $(\beta=0.222, \mathrm{t}=3.594, \mathrm{p}<0.001)$ have a positively significant and direct predictor of consumer motive. However, price $(\beta=0.444$, $\mathrm{t}=8.884, \quad \mathrm{p}>0.001)$ and promotion $(\beta=0.059$, $\mathrm{t}=0.980, \quad \mathrm{p}>0.05)$ did not significant with consumer motive. Therefore, H6a, H6b and H6c are supported, while, only H6d is not supported and was rejected.

On the contrary, the predictor of marketing mix also has mixed result of relationship with customer preference where, price $(\beta=0.151$, $\mathrm{t}=2.480, \quad \mathrm{p}<0.01)$, product $(\beta=0.395, \mathrm{t}=6.195$, $\mathrm{p}<0.001)$, place $(\beta=0.058, \mathrm{t}=0.996, \mathrm{p}>0.05)$ and promotion $(\beta=0.227, t=3.903, p<0.001)$. Findings also revealed only place is not significant with customer preference. Meanwhile for price, product and promotion were significant at $\mathrm{p}$ value less than 0.01 and less than 0.001 respectively. Hence, H7a, H7b, and H7d were supported.

4.5.1 The hypotheses testing for mediating effect: Consumer lifestyle as a mediator in urban and urban area.

The bootstrapping results show that the consumer lifestyle is the mediator of the relationship between consumer value and consumption pattern ( $\beta=0.284, t=7.897, p=0.000)$, consumer motive and consumption pattern $(\beta=0.321, \mathrm{t}=9.717$, $\mathrm{p}=0.000)$, and consumer preference and consumption pattern $(\beta=0.349, \quad \mathrm{t}=12.406$, $\mathrm{p}=0.000)$ as postulated in table 4.26 below. Findings showed all mediator were supported. Thus, we accepted H8a, H8b and H8c.

Table 4.11

The mediating effect of consumer lifestyle for consumption pattern model.

\begin{tabular}{llllllllll}
\hline \multirow{2}{*}{ Hypotheses } & \multirow{2}{*}{ Hypotheses Path } & $\begin{array}{l}\text { Path } \\
\text { a }\end{array}$ & $\begin{array}{l}\text { Path } \\
\text { B }\end{array}$ & $\begin{array}{l}\text { Indirect } \\
\text { Effect }\end{array}$ & $\begin{array}{l}\text { Std. } \\
\text { Error }\end{array}$ & $\begin{array}{l}\text { T- } \\
\text { value }\end{array}$ & $\begin{array}{l}\text { 95\% } \\
\text { LL }\end{array}$ & $\begin{array}{l}\text { 95\% } \\
\text { UL }\end{array}$ & \multirow{2}{*}{ Decision } \\
\hline H8a & CV -> CL - C CONP & 0.690 & 0.412 & 0.284 & 0.036 & 7.897 & 0.214 & 0.355 & Mediate \\
H8b & CM-> CL ->CONP & 0.583 & 0.550 & 0.321 & 0.033 & 9.717 & 0.256 & 0.385 & Mediate \\
H8c & CP - > CL ->CONP & 0.641 & 0.545 & 0.349 & 0.029 & 12.046 & 0.293 & 0.406 & Mediate \\
\hline
\end{tabular}

4.5.2 The hypotheses testing for mediating effect: Consumer value, consumer motive and consumer preference as a mediator in urban area

Consumer value, consumer motive and consumer preference were mediator for the relationship marketing mix (price, product, place and promotion), consumer lifestyle and consumption pattern. Bootstrapping results indicate that consumer value is the mediator of the relationship between price, consumer lifestyle and consumption pattern $(\beta=0.090$, $\mathrm{t}=3.733, \mathrm{p}=0.000$ ), a mediator in relationship between product, consumer lifestyle and consumption pattern $(\beta=0.121, \quad \mathrm{t}=5.049$, $\mathrm{p}=0.000$ ), a mediator in relationship between place, consumer lifestyle and consumption pattern $(\beta=0.162, t=5.778, p=0.000)$, also a mediator in relationship between promotion, consumer lifestyle and consumption pattern $(\beta=0.127, t=5.525, p=0.000)$. The findings indicated consumer value mediates the relationship marketing mix (price, product, place and promotion), consumer lifestyle and consumption pattern. Therefore, we accept H9a, H9b, H9c and H9d. Table 4.12 below 
indicated mediating results for construct consumer value, consumer motive and consumer preference.

Bootstrapping results also show that consumer motive mediates the relationship between price, consumer lifestyle and consumption pattern $(\beta=0.092, \quad \mathrm{t}=5.432$, $\mathrm{p}=0.000$ ), mediates the relationship between product, consumer lifestyle and consumption pattern $(\beta=0.124, t=7.268, p=0.000)$, mediates the relationship between place, consumer lifestyle and consumption pattern $(\beta=0.138$, $\mathrm{t}=7.248, \quad \mathrm{p}=0.000)$, and mediates the relationship between promotion, consumer lifestyle and consumption pattern $(\beta=0.110$, $\mathrm{t}=6.452, \mathrm{p}=0.000)$. Hence, as result of bootstrapping supported consumer motive as a mediator in the consumption pattern model for rural area, H10a, H10b, H10c and H10d were accepted.

In addition, results of bootstrapping indicate consumer preference also mediates the relationship between price, consumer lifestyle and consumption pattern $(\beta=0.073, t=3.159$, $\mathrm{p}=0.000$ ), mediates the relationship between product, consumer lifestyle and consumption pattern $\quad(\beta=0.094, \quad \mathrm{t}=11.730, \quad \mathrm{p}=0.000)$, mediates the relationship between place, consumer lifestyle and consumption pattern ( $\beta=0.147, t=14.720, p=0.000)$, mediates the relationship between promotion, consumer lifestyle and consumption pattern $(\beta=0.076$, $\mathrm{t}=4.761, \mathrm{p}=0.000)$. Thus, as result of bootstrapping supported consumer motive as a mediator in the consumption pattern model for rural area, H11a, H11b, H11c and H11d were accepted.

Table 4.12

The mediating effect of consumer value, consumer motive and consumer preference for consumption pattern model.

\begin{tabular}{|c|c|c|c|c|c|c|c|c|c|c|}
\hline $\begin{array}{l}\text { Hypothese } \\
\text { s }\end{array}$ & Hypotheses Path & $\begin{array}{l}\text { Path } \\
\text { A }\end{array}$ & $\begin{array}{l}\text { Path } \\
\text { B }\end{array}$ & $\begin{array}{l}\text { Path } \\
\text { C }\end{array}$ & $\begin{array}{l}\text { Indirect } \\
\text { Effect }\end{array}$ & $\begin{array}{l}\text { Std. } \\
\text { Error }\end{array}$ & $\begin{array}{l}\text { T- } \\
\text { value }\end{array}$ & $\begin{array}{l}95 \% \\
\text { LL }\end{array}$ & $\begin{array}{l}95 \% \\
\text { UL }\end{array}$ & Decision \\
\hline H9a & $\begin{array}{l}\mathrm{PR} \rightarrow \mathrm{CV} \rightarrow \mathrm{CL} \rightarrow \\
\mathrm{CONP}\end{array}$ & 0.629 & 0.428 & $\begin{array}{l}0.34 \\
3\end{array}$ & 0.092 & 0.017 & 5.432 & $\begin{array}{l}0.05 \\
9\end{array}$ & 0.126 & Mediate \\
\hline $\mathrm{H} 9 \mathrm{~b}$ & $\begin{array}{l}\mathrm{PD} \rightarrow \mathrm{CV} \rightarrow \mathrm{CL} \rightarrow \\
\mathrm{CONP}\end{array}$ & 0.681 & 0.493 & $\begin{array}{l}0.36 \\
8\end{array}$ & 0.124 & 0.019 & 7.268 & $\begin{array}{l}0.09 \\
0\end{array}$ & 0.157 & Mediate \\
\hline $\mathrm{H} 9 \mathrm{c}$ & $\begin{array}{l}\mathrm{PL} \rightarrow \mathrm{CV} \rightarrow \mathrm{CL} \rightarrow \\
\mathrm{CONP}\end{array}$ & 0.616 & 0.566 & $\begin{array}{l}0.39 \\
5\end{array}$ & 0.138 & 0.017 & 7.248 & $\begin{array}{l}0.10 \\
0\end{array}$ & 0.175 & Mediate \\
\hline H9d & $\begin{array}{l}\mathrm{PRO} \rightarrow \mathrm{CV} \rightarrow \mathrm{CL} \\
\rightarrow \mathrm{CONP}\end{array}$ & 0.682 & 0.437 & $\begin{array}{l}0.36 \\
8\end{array}$ & 0.110 & 0.023 & 6.452 & $\begin{array}{l}0.07 \\
6\end{array}$ & 0.143 & Mediate \\
\hline $\mathrm{H} 10 \mathrm{a}$ & $\begin{array}{l}\mathrm{PR} \rightarrow \mathrm{CM} \rightarrow \mathrm{CL} \rightarrow \\
\mathrm{CONP}\end{array}$ & 0.587 & 0.272 & $\begin{array}{l}0.45 \\
5\end{array}$ & 0.073 & 0.008 & 3.159 & $\begin{array}{l}0.02 \\
8\end{array}$ & 0.118 & Mediate \\
\hline $\mathrm{H} 10 \mathrm{~b}$ & $\begin{array}{l}\mathrm{PD} \rightarrow \mathrm{CM} \rightarrow \mathrm{CL} \rightarrow \\
\mathrm{CONP}\end{array}$ & 0.642 & 0.311 & $\begin{array}{l}0.47 \\
0\end{array}$ & 0.094 & 0.010 & $\begin{array}{l}11.73 \\
0\end{array}$ & $\begin{array}{l}0.07 \\
8\end{array}$ & 0.110 & Mediate \\
\hline $\mathrm{H} 10 \mathrm{c}$ & $\begin{array}{l}\mathrm{PL} \rightarrow \mathrm{CM} \rightarrow \mathrm{CL} \rightarrow \\
\mathrm{CONP}\end{array}$ & 0.704 & 0.396 & $\begin{array}{l}0.52 \\
8\end{array}$ & 0.147 & 0.016 & $\begin{array}{l}14.72 \\
0\end{array}$ & $\begin{array}{l}0.12 \\
8\end{array}$ & 0.167 & Mediate \\
\hline H10d & $\begin{array}{l}\mathrm{PRO} \rightarrow \mathrm{CM} \rightarrow \mathrm{CL} \\
\rightarrow \mathrm{CONP}\end{array}$ & 0.570 & 0.297 & $\begin{array}{l}0.45 \\
0\end{array}$ & 0.076 & 0.007 & 4.761 & $\begin{array}{l}0.04 \\
5\end{array}$ & 0.108 & Mediate \\
\hline H11a & $\begin{array}{l}\mathrm{PR} \rightarrow \mathrm{CP} \rightarrow \mathrm{CL} \rightarrow \\
\mathrm{CONP}\end{array}$ & 0.619 & 0.346 & $\begin{array}{l}0.45 \\
1\end{array}$ & 0.097 & 0.015 & 6.439 & $\begin{array}{l}0.06 \\
7\end{array}$ & 0.126 & Mediate \\
\hline $\mathrm{H} 11 \mathrm{~b}$ & $\begin{array}{l}\mathrm{PD} \rightarrow \mathrm{CP} \rightarrow \mathrm{CL} \rightarrow \\
\mathrm{CONP}\end{array}$ & 0.692 & 0.398 & $\begin{array}{l}0.47 \\
4\end{array}$ & 0.131 & 0.015 & 8.703 & $\begin{array}{l}0.10 \\
1\end{array}$ & 0.160 & Mediate \\
\hline H11c & $\begin{array}{l}\mathrm{PL} \rightarrow \mathrm{CP} \rightarrow \mathrm{CL} \rightarrow \\
\mathrm{CONP}\end{array}$ & 0.578 & 0.487 & $\begin{array}{l}0.49 \\
9\end{array}$ & 0.140 & 0.012 & $\begin{array}{l}11.70 \\
5\end{array}$ & $\begin{array}{l}0.11 \\
7\end{array}$ & 0.164 & Mediate \\
\hline H11d & $\begin{array}{l}\mathrm{PRO} \rightarrow \mathrm{CP} \rightarrow \mathrm{CL} \\
\rightarrow \mathrm{CONP}\end{array}$ & 0.633 & 0.356 & $\begin{array}{l}0.45 \\
8\end{array}$ & 0.103 & 0.014 & 7.372 & $\begin{array}{l}0.07 \\
6\end{array}$ & 0.131 & Mediate \\
\hline
\end{tabular}




\subsection{Summary of the Findings}

Analysis being done to examine or identify the relationship between the dependent variables and independent variables and summary of results is shown in Table 4.2.2

Table 4.2.2

Summary of The Hypotheses Testing Results for Urban Area

\begin{tabular}{|c|c|c|c|c|}
\hline Hypotheses & Items & Result & & \\
\hline & & Full Model & Rural Model & Urban Model \\
\hline H1 & $\begin{array}{l}\text { Consumer lifestyle is a direct } \\
\text { predictor of consumption pattern. }\end{array}$ & Supported & Supported & Supported \\
\hline H2 & $\begin{array}{l}\text { Consumer value is a direct predictor } \\
\text { of consumer lifestyle. }\end{array}$ & Supported & Supported & Supported \\
\hline H3 & $\begin{array}{l}\text { Consumer motive is a direct } \\
\text { predictor of consumer lifestyle. }\end{array}$ & Supported & Supported & Supported \\
\hline H4 & $\begin{array}{l}\text { Consumer preference is a direct } \\
\text { predictor of consumer lifestyle. }\end{array}$ & Supported & Supported & Supported \\
\hline H5a & $\begin{array}{l}\text { Price is a direct predictor of } \\
\text { consumer value. }\end{array}$ & Supported & Supported & Supported \\
\hline H5b & $\begin{array}{l}\text { Product is a direct predictor of } \\
\text { consumer value. }\end{array}$ & Supported & Supported & Supported \\
\hline H5c & $\begin{array}{l}\text { Place is a direct predictor of } \\
\text { consumer value. }\end{array}$ & Supported & Supported & Supported \\
\hline H5d & $\begin{array}{l}\text { Promotion is a direct predictor of } \\
\text { consumer value. }\end{array}$ & Supported & Supported & Supported \\
\hline H6a & $\begin{array}{l}\text { Product is a direct predictor of } \\
\text { consumer motive. }\end{array}$ & Supported & $\begin{array}{l}\text { Not } \\
\text { Supported }\end{array}$ & Supported \\
\hline H6b & $\begin{array}{l}\text { Price is direct predictor of consumer } \\
\text { motive. }\end{array}$ & Supported & Supported & Supported \\
\hline H6c & $\begin{array}{l}\text { Place is a direct predictor of } \\
\text { consumer motive. }\end{array}$ & Supported & Supported & Supported \\
\hline H6d & $\begin{array}{l}\text { Advertising is a direct predictor of } \\
\text { consumer motive. }\end{array}$ & $\begin{array}{l}\text { Not } \\
\text { supported }\end{array}$ & $\begin{array}{l}\text { Not } \\
\text { supported }\end{array}$ & $\begin{array}{l}\text { Not } \\
\text { supported }\end{array}$ \\
\hline H7a & $\begin{array}{l}\text { Price is direct predictor of consumer } \\
\text { preference. }\end{array}$ & Supported & Supported & Supported \\
\hline H7b & $\begin{array}{l}\text { Product is a direct predictor of } \\
\text { consumer preference. }\end{array}$ & Supported & Supported & Supported \\
\hline H7c & $\begin{array}{l}\text { Place is a direct predictor of } \\
\text { consumer preference. }\end{array}$ & Supported & Supported & $\begin{array}{l}\text { Not } \\
\text { Supported }\end{array}$ \\
\hline H7d & $\begin{array}{l}\text { Promotion is a direct predictor of } \\
\text { consumer preference. }\end{array}$ & Supported & Supported & Supported \\
\hline H8a & $\begin{array}{l}\text { Consumer lifestyle mediates the } \\
\text { relationship between consumer value } \\
\text { and consumption pattern. }\end{array}$ & Supported & Supported & Supported \\
\hline H8b & $\begin{array}{l}\text { Consumer lifestyle mediates the } \\
\text { relationship between consumer } \\
\text { motive and consumption pattern. }\end{array}$ & Supported & Supported & Supported \\
\hline
\end{tabular}




\begin{tabular}{|c|c|c|c|c|}
\hline H8c & $\begin{array}{l}\text { Consumer lifestyle mediates the } \\
\text { relationship between consumer } \\
\text { preference and consumption } \\
\text { pattern. }\end{array}$ & Supported & Supported & Supported \\
\hline$\overline{\mathrm{H9a}}$ & $\begin{array}{l}\text { Consumer value mediates the } \\
\text { relationship between price and } \\
\text { consumer lifestyle. }\end{array}$ & Supported & Supported & Supported \\
\hline H9b & $\begin{array}{l}\text { Consumer value mediates the } \\
\text { relationship between place and } \\
\text { consumer lifestyle. }\end{array}$ & Supported & Supported & Supported \\
\hline H9c & $\begin{array}{l}\text { Consumer value mediates the } \\
\text { relationship between product and } \\
\text { consumer lifestyle. }\end{array}$ & Supported & Supported & Supported \\
\hline H9d & $\begin{array}{l}\text { Consumer value mediates the } \\
\text { relationship between promotion and } \\
\text { consumer lifestyle. }\end{array}$ & Supported & Supported & Supported \\
\hline H10a & $\begin{array}{l}\text { Consumer motive mediates the } \\
\text { relationship between price and } \\
\text { consumer lifestyle. }\end{array}$ & Supported & Supported & Supported \\
\hline H10b & $\begin{array}{l}\text { Consumer motive mediates the } \\
\text { relationship between product and } \\
\text { consumer lifestyle. }\end{array}$ & Supported & Supported & Supported \\
\hline H10c & $\begin{array}{l}\text { Consumer motive mediates the } \\
\text { relationship between place and } \\
\text { consumer lifestyle. }\end{array}$ & Supported & Supported & Supported \\
\hline H10d & $\begin{array}{l}\text { Consumer motive mediates the } \\
\text { relationship between promotion and } \\
\text { consumer lifestyle. }\end{array}$ & Supported & Supported & Supported \\
\hline H11a & $\begin{array}{l}\text { Consumer preference mediates the } \\
\text { relationship between price and } \\
\text { consumer lifestyle. }\end{array}$ & Supported & Supported & Supported \\
\hline H11b & $\begin{array}{l}\text { Consumer preference mediates the } \\
\text { relationship between product and } \\
\text { consumer lifestyle. }\end{array}$ & Supported & Supported & Supported \\
\hline H11c & $\begin{array}{l}\text { Consumer preference mediates the } \\
\text { relationship between place and } \\
\text { consumer lifestyle. }\end{array}$ & Supported & Supported & Supported \\
\hline H11d & $\begin{array}{l}\text { Consumer preference mediates the } \\
\text { relationship between promotion and } \\
\text { consumer lifestyle. }\end{array}$ & Supported & Supported & Supported \\
\hline
\end{tabular}




\section{Conclusion}

The findings of this study are according to the five objectives of the study that being populated. Firstly, consumption patterns of Malaysians changed due to the inflation rate hikes at the end of 2016 and also beginning of 2017. Even though there is a little economic growth between 4.3 percent to 4.8 percent, the volatile oil price has affected this economic growth. Due to this, consumers are burdened with the increase of food prices. Next, the CPI for transportation increased to $113.4 \%$ in 2017 meanwhile, for foods and non-alcoholic beverages increased to 128.8 percent. In addition, the anaemic wage growth has also contributed to these consumption pattern changes. Secondly is regarding price increase. Major contributor of price increase is oil price hikes. As an example, on food and non-alcoholic beverages, which accounted 30.2 per cent in the CPI weights, the increase was led by oils and fats (38.3 per cent) and vegetables ( 9.5 per cent). Along with the oil price hikes, GST implementation has also added to price increase with an added cost to the consumers. This happened when many consumers were on a buying spree prior to the implementation date of GST to avoid GST [44]. Next is about the relationships between the specified variables with consumption pattern. Consumption pattern in urban area and rural area are determined by consumer lifestyles, value, motivation and preference. Consumer lifestyles demonstrate how consumers think, live, act, and behave influenced by individual consumers' demographic background, experiences, current situation or action, socio-economic characteristics, and behavioural tendencies. This generalize more realistic multi-dimensional clusters of rural and urban consumers' consumption pattern for a particular product/brand. Consistent with previous studies [45]; [46] Malaysians consumption pattern are influenced by consumer lifestyle, value, motivations and preferences. Followed by a new consumption model for Malaysian consumers

The new model for Malaysian consumer's consumption pattern is as below would be different from previous [45]; [7]; [47] as it is an extended model from the previous model. The R 2 of the three models shows about 50 percent of the variables explained in the model; full model of Malaysian consumers consumption pattern R2 is $48.1 \%$, consumption pattern in rural area at $50.5 \%$ and in urban area at $46 \%$ of variance. From these three models, the consumption pattern model in rural areas postulates the best model. However, in the rural and urban model, there were two insignificant relationships in each model while only one insignificant relationship was found in full model. However, the new consumption model for Malaysian consumers proved that advertising is not a predictor for consumer motive. Finally, about a wise strategy and policy of consumer consumption pattern. Malaysia should have more low-cost retail stores as Tesco, Giant and Mydin in rural areas. This is to minimize consumers spending and accelerate economic growth in these areas. Secondly, although GST was implemented in 2015, the level of awareness among Malaysian consumers is still at its infancy level. Therefore, the government should take proactive measures to promote GST to Malaysian consumers. Finally, since the price of commodities is influenced by high fuel prices, consumers should consider wise usage of fuel by optimizing public transportation or carpools. Future, research is suggested to conduct a research on the countries policy makers and how it affects the level of awareness among Malaysian consumers.

\section{Acknowledgement}

Yaty Sulaiman, Abdul Shukor Shamsudin, Yeoh Khar Kheng and Abdul Rahim Othman are Senior Lecturers and Associate Professors at School of Business Management, Universiti Utara Malaysia, Kedah, Malaysia. 


\section{References}

[1] Yaty Sulaiman, Nik Kamariah Nik Mat \& Noor Hasmini Abd Ghani. 2014. Constructing a Consumption Model for Malaysian Consumers. Journal of Marketing Management. December 2014 (2): 49.

[2] Colen, L., Melo, P. C., Abdul-Salam, Y., Roberts, D., Mary, S., \& Paloma, S. G. Y. 2018. Income elasticities for food, calories and nutrients across Africa: A metaanalysis. Food Policy77: 116-132

[3] Malaysia Inflation Rate.htm, retrieved on March 3, 2014.

[4] Tjiptono, F. (2018). Pemasaran strategik. 4th ed. Yogyakarta: Andi publisher.

[5] Hawkins, D. I., Roupe, D., \& Coney, K. A. (1981). The influence of geographic subcultures in the United States. NAAdvances in Consumer Research, 8, 713717

[6] Veenma, K. S., Kistemaker, C., Lowik, M. T. H., \& Hulshof, K. F. A. M. (1995). Sociodemographic, psycho-social and lifestyle factors affecting consumption of convenience food. E-European Advances in Consumer Research, 2, 149-156.

[7] Munisamy, J., \& Hoo, W. C. (2008). Relationship between marketing mix strategy and consumer motive: An empirical study in major Tesco stores. Unitar E-Journal, 4 (2), 41-55.

[8] Behera, J. P. (2018). Impact of Service Quality on Customer Loyalty in Indian Banking Sector in Odisha, (June). https://doi.org/10.18231/24549150.2018.0165

[9] Khan, H., Razi,A., \& et. al. (2011). Identifying consumer lifestyle. Interdisciplinary Journal of Contemporary Research In Business. Vol. 3. No. 8. 249-268.

[10] Ansbacher, L. H., (1967). Life Style: A Historical and Systematic Review. Journal of Individual Psychology, 23, 193.

[11] Bin, S., \& Dowlatabadi, H. (2005). Consumer lifestyle approach to US energy use and the related $\mathrm{CO}_{2}$ emissions. Energy Policy, 33, 197-208.

[12] Feldman, S.D., \& Thielbar G.W., (1971). Life Styles: diversity in American society, Boston, Little, Brown\&Co , 46.

[13] Smith, J.B. and Colgate, M. (2007). Customer Value Creation: a Practical Framework. Journal of Marketing Theory and Practice, 15(1): 7-23.
[14] Payne, J.D., Ellenbogen, J.M., Walker, M.P., and Stickgold, R. (2008). The role of sleep in Peter, P.J. \& Donnelly, J.H. (2007). Marketing management: Knowledge and skills (8thed). New York: McGraw-Hill

[15] Ko, S., Norum, P., \& Hawley, J.M. (2010). Consumer value structures reflected in clothing advertisement. Journal of Fashion Marketing and Management, Vol. 14, No. 3, pp. 451-468.

[16] Kahle, L. R. (1996). Social values and consumer behaviour: Research from the list of values, in Vigaray, M., D. J., \& Hota, M. Schwartz values, consumer values and segmentation: The Spanish fashion apparel case. Lille Economie \& Management, 1-31.

[17] Gale, B.T. (1994). Managing Customer Value: Creating Quality And Service That Customers Can See, Free Press, New York.

[18] Hamel, G. and Prahalad, C.K. (1994). Competing for the Future. Boston, MA: Harvard Business

[19] Woodruff, R. B. (1997). Customer value: The next source for competitive advantage. Journal of Academy of Marketing Science, 25, 139-153.

[20] Flint, D.J., Woodruff, R. and Gardial, S. (2002). Exploring the Phenomenon of Customers' Desired Value Change in a Business-to-Business Context. Journal of Marketing, 66(4): 102-117.

[21] Rajpurohit, R.C.S.,\& Vasita, M.L. (2011). Consumer preferences and satisfaction towards various mobile phone service providers. Gurukul Business Review. Vol. 7. $1-11$.

[22] Daud, M. A. (2013). Awareness of brand and increasing customer's demand for FMCG products in rural market: The rural market of Uttar Pradesh. International Journal of Engineering and Management Sciences. Vol. 4(1). 79-82.

[23] Kotler, P., \& Keller, K. L. (2012). Marketing management (14th ed.). Upper Saddle River, NJ: Prentice Hall.

[24] Venter, P. \& Van Rensburg, M.J. (2011). Strategic marketing: Theory and application for competitive advantage. 1step. Cape Town: Oxford University press.

[25] Singh, M. Marketing Mix of 4P'S for Competitive Advantage. IOSR Journal of 
Business and Management (IOSRJBM). 2012, Volume 3, Issue 6 (Sep,-Oct.).

[26] Harahap, N. Z. (2018). Pengaruh Kualitas Produk, Harga dan Promosi terhadap Keputusan Pembelian Mie Instan Merek Sedaap pada Mahasiswa Asrama Putri Universitas Sumatera Utara

[27] Kotler P, Armstrong G. (2010). Principles of marketing; Pearson Prentice Hall, 13th Ed. New Jersey, NJ.

[28] Borden, N. H. (1984). The concept of marketing mix. Journal of Advertising Research, 1(9), 2-7.

[29] Jones, .S. (2007). Exploring corporate strategy: text $\&$ cases. 8 th edition.

[30] Tjiptono,F (2000). Manajemen Jasa. Penerbit Andi Yogyakarta.

[31] Martin, M. Business, MarketingMarketing Mix.

2014.https://www.cleverism.com/placefour-ps-marketing-mix.

[32] Kurniawati, W. A. C. (2017). Pengaruh Lokasi Perumahan, Harga Perumahan Dan Citra Merek Terhadap Keputusan Nasabah Mengambil Kredit Kepemilikan Rumah (Kpr) Syariah (Studi Kasus Nasabah Btn Syariah Surakarta). Institut Agama Islam Negeri Surakarta.

[33] Stanton W. 1. Etzel M. I., Walker B.1. (2005), "Fundamentals of Marketing",McGraw Hill Publications, New Delhi

[34] Utomo, I. B., Amrison, \& Bustomi. (2018). Model of purchase decision: A study on consumer of PRODUGEN brand milk product. International Journal of Economics, Business and Management Research, 2(2), 507-514.

[35] Putra, E. (2019). The Influence of Promotion and Brand Image toward Purchase Decision Of Honda Vario. Jurnal Apresiasi Ekonomi, 7(1), 121-130

[36] Pushpavathani, K., \& Kumaradeepan, V. (2013). Consumer's preference and consumer buying behaviour of foot ware industry in Vavuniya District, Sri Lanka. Trans Asian Journal of Marketing \& Management Research, vol.2, Issue 3-4, Issn 2279-0667.

[37] Duhaime, G., M. Chabot and P. Fréchette (1998). Portrait économique desménages inuit du Nunavik en 1995. In G. Duhaime (Ed.), Les impacts socioéconomiques de la contamination de la chaîne alimentaire au Nunavik. Québec,GÉTIC
[38] Kara, A., Kaynak, E., \& Kucukemiroglu, O. (1997). Marketing strategies for fast-food restaurants: A customer view. British Food Journal, 99(9), 318-324. https://doi.org/10.1108/000707097101940 14

[39] Armstrong, C., and R. Vashishtha, 2012. Executive stock options, differential ritaking incentives, and firm value. Journal of Financial Economics 104: 70-88.

[40] McCarthy, K., Rojas, K., Niemann, M., Palmowski, D., Peters, K., Stankiewicz, A., 2011. Basic petroleum geochemistry for source rock evaluation. Oilf. Rev. 23, 3243.

[41] Ndungu, H. (2013). The effect of internal controls on revenue generation: A case study of the University of Nairobi Enterprise and Services Limited.

[42] Kombenjamas W., \& Lertrattananon, N. (2011). Services Marketing Mix of Foreign Coffee Franchiser in Bangkok, Master Thesis in Business Studies: EFO 705, Mälardalen University (Mälardalens högskola)

[43] Hair, J. F., Black, W. C., Babin, B. J., Anderson, R. E., \& Tatham, R. L. (2006). Multivariate data analysis (6th ed.). USA: Prentice-Hall.

[44] The Strait Times Asia. (March 31, 2015). Buying spree in Malaysia to avoid 6\% GST from April 1. Retrieved from http://www.straitstimes.com/news/asia/sou th-east-asia/story/buying-spree-malaysiaavoid-gst-wednesday-20150331on 5 May 2015 
[45] Hawkins, D. I., Roupe, D., \& Coney, K. A. (1981). The influence of geographic subcultures in the United States. NAAdvances in Consumer Research, 8, 713717.

[46] Kim, J. O., \& Jin, B. (2001). Korean consumers' patronage of discount stores: Domestic vs. multinational discount stores shoppers' profile. Journal of Consumer Marketing, 18 (3), 236-255.
[47] Veenma, K. S., Kistemaker,, C., Lowik, M. T. H., \& Hulshof, K. F. A. M. (1995). Sociodemographic, psycho-social and lifestyle factors affecting consumption of convenience food. E-European Advances in Consumer Research, 2,149-156. www.tradingeconomics.com, retrieved March 12, 2014 